\section{Department of Trade and Industry (DTI) IV: A marketing assistance to micro, small, and medium enterprises and its financial impact: Inputs to marketing plan}

\author{
Paterno, Arlani $\square$ \\ Laguna College of Business and Arts, Philippines (arlanipaterno@gmail.com)
}

Received: 5 August 2021

Revised: 8 August 2021 DOI: $10.5861 /$ ijrsm.2021.m058

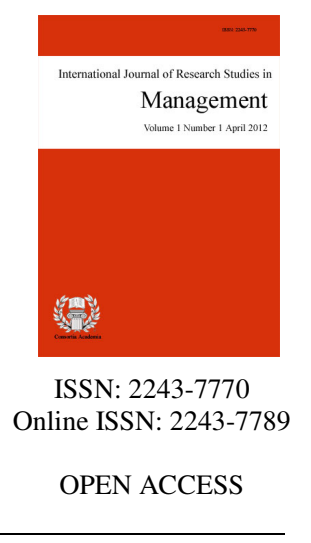

\title{
Abstract
}

This study determined the level of marketing assistance being provided by the Department of Trade and Industry (DTI) IV-A to micro, small, and medium enterprises (MSMEs) and the level of its financial impact. The descriptive correlational method was utilized, and the respondents were the marketing assisted MSMEs in the CALABARZON region. The researcher used a survey questionnaire and a simple mean and four-point Likert scale, and Pearson product moment correlation was used for its statistical treatment. Consequently, all of the indicators of DTI IV-A marketing assistance were very strong. Specifically, the level of marketing assistance in terms of physical trade fair, virtual trade fair, product development, seminars and training, and provision of hubs and stores were all verbally interpreted as Very High as assessed by the MSMEs owners. Moreover, all the indicators of the marketing assistance' financial impact was also very sturdy. In particular, the level of the financial impact in terms of revenue, marketing cost, and net profit were all verbally interpreted as Very High as assessed by the MSMEs owner. Accordingly, there was a significant relationship between the level of marketing assistance being provided by the Department of Trade and Industry (DTI) IV-A and its financial impact to the micro, small, and medium enterprises (MSMEs).

Keywords: marketing assistance, financial impact, micro enterprises, small enterprises, medium enterprises 


\section{Department of Trade and Industry (DTI) IV: A marketing assistance to micro, small, and medium enterprises and its financial impact: Inputs to marketing plan}

\section{Introduction}

Micro, small, and medium-sized enterprises (MSMEs) are the backbone of many economies worldwide that provide income and employment generation to a large number of people around the globe. They are also the major contributors to the Gross Domestic Product (GDP) of a certain country that gauge the size of an economy and the growth rate. A vibrant MSME sector is thus an indication of a thriving and growing economy. They help reduce poverty by creating jobs for the country's growing labor force. They stimulate economic development in rural and far-flung areas. They serve as valuable partners to large enterprises as suppliers and providers of support services. They serve as the breeding ground for new entrepreneurs and large corporations (Venkatesh \& Kumari, 2015).

Similarly, in the case of the Philippines, as stated in the Philippine Statistics Authority (PSA) data of 2018, MSMEs are crucial for the economy as they constitute $99.52 \%$ or 998,342 of the estimated $1,003,111$ business enterprises and contribute $57.8 \%$ to the GDP and $25 \%$ of the country's total exports revenue and $60 \%$ of the country's total exporter in 2018. These businesses are geographically spread all over the Philippines and represent a significant portion of wholesale and retail trade; repair of motor vehicles and motorcycles, accommodation and food service activities, manufacturing, other service activities, and financial and insurance activities sectors. Together, these MSMEs generated a total of 5,714,262 jobs or $63.19 \%$ of the country's total employment.

Opportunely, the Department of Trade and Industry (DTI), the executive department of the Philippine Government, is tasked as the main economic catalyst that enables innovative, competitive, job-generating, inclusive business, and empowers consumers, acts as a facilitator for intensified private sector activity to accelerate and sustain economic growth through comprehensive industrial growth strategy, progressive and socially responsible trade liberalization and deregulation programs and policymaking designed for the expansion and diversification of Philippine trade - both domestic and foreign.

The DTI is responsible for realizing the country's goal of a globally competitive and innovative industry and services sector that contributes to inclusive growth and employment generation. Pursuant to the Philippine Development Plan (PDP) 2017-2022, it shall endeavor to reduce inequality and poverty by expanding economic opportunities in industry and services, and by increasing the access particularly of micro, small and medium enterprises (MSMEs), cooperatives, and overseas Filipinos (OFs) to these opportunities. The DTI commits to effect good governance by delivering public service that is predictable, participatory, accountable, efficient, transparent, and honest.

The researcher, who is currently employed at the Department of Trade and Industry Regional Office IV-A under the SME Development Division as Regional Trade Promotion Officer (RTPO) for Local Marketing, deemed it is an opportunity to explore not only the marketing aspect but its financial impact on its beneficiaries. Consequently, this quantitative research is conducted to validate and explore the marketing assistance being provided by the Department of Trade and Industry to Micro, Small, and Medium Enterprises in the CALABARZON region. Moreover, this quantitative research is intended to determine the marketing assistances that provide great impact or those that need improvement and even the services that are not provided yet by the department that need to be addressed. As a result, the researcher formulated an enhancement plan to continuously improve the marketing assistance being provided by the Department of Trade and Industry for the region's business owners of MSMEs. 
This study was supported by different theories of the following well-known scholars. In the formulation of a theoretical perspective of the study as regards the financial impact of DTI marketing assistance to micro, small, medium enterprises in Region IV-A which served as a basis to improve practices, the research was guided by the Opportunity-Based Theory by Peter F. Drucker as cited by Tidd and Bessant (2020) that innovative firms outperform, in both employment and sales, firms that fail to innovate. This theory also states that entrepreneurs excel at seeing and taking advantage of possibilities created by social, technological, and cultural changes. Furthermore, the theory stresses the importance of financial, social, and human. Thus, mentioned that access to resources enhances the individual's ability to detect and act upon discovered opportunities. Financial, social, and human capital represents three classes of theories under the resource-based entrepreneurship theories. This theory states that entrepreneurs do not cause change but exploit the opportunities that change (in technology, consumer preference, etc.) creates. This defines entrepreneurs and entrepreneurship: the entrepreneur always searches for change, responds to it, and exploits it as an opportunity.

An opportunity opens up to another: An opportunity well utilized opens up to another. Opportunities are in sizes and phases. Just as in the home, an outer door leads to an inner one so it is with opportunities. Opportunity elevates people and organization: It was observed that opportunity does not reduce people rather it increases them. Pramanik (2015) also mentioned that the opportunity-based approach recognizes the important role of the entrepreneur in the formation of, and the decision to, pursue entrepreneurial opportunities. Much has been written on the objective dimensions of entrepreneurs (age, level of education, language, etc.) The interest lies in the subjective entrepreneurial dimensions in opportunity formation and opportunity decision. A subjectivist orientation can draw on Lachmann, an Austrian economist who stated that social phenomena are the outcome of human action guided by plans and prompted by mental acts. He also mentioned that the entrepreneur creates by conjecture and reasoned imagination, an imagined future that, though the unknown is not unimaginable. This entrepreneurial ability to create the imagined future, an entrepreneurial attribute we call prospection, is important in opportunity formation, opportunity decision, and opportunity exploitation.

Furthermore, Maciariello (2018) cited that Drucker's master project as a social ecologist was to describe and illustrate how to manage discontinuities through processes of continuity and change. As he applied his methodology to the enterprise, his emphasis was on providing customer value and adapting to change through innovation. Drucker established the management philosophy of management by objectives (MBO) to implement strategy and called MBO the fundamental strategy of the business. Drucker's work on strategy benefits by being organized as a configuration of interrelated parts. The configuration is titled the 'Drucker strategic management system' (DSMS). The DSMS consists of humanly determined values focused on the welfare of individuals, organizations, and society. The DSMS has been used by many executives but also has its critics.

The principles of the Opportunity-Based Theory are manifested in the study since the researcher believes that MSMEs excel in seeing and taking advantage of possibilities created by financial, social, and human and MSMEs' access to resources enhances their ability to detect and act upon discovered opportunities. This is very evident with the estimated numbers of business enterprises in the country and their contribution to the economy in terms of Gross Domestic Product (GDP) that is used to estimate the size of an economy and growth rate and its total job generation.

In addition, the Marketing Orientation Theory by Ajay Kohli and Bernie Jaworski was also utilized in the study. The theory was cited by Payne et al. (2017) that market orientation is the organization-wide generation of market intelligence, dissemination of the intelligence across departments, and organization-wide responsiveness to it. Moreover, it depicts that the customer value proposition (CPV) has a critical role in communicating how a company aims to provide value to customers. The theory defined market orientation as constituting three components: The organization-wide generation of market intelligence that pertains to current and future customer needs; Dissemination of the intelligence among the departments of the organization; and 
Organization-wide response to the knowledge derived from the market intelligence. According to them, the marketing concept is a business philosophy, whereas the term market orientation refers to the actual implementation of the marketing concept. They added that a market orientation appears to provide a unifying focus for the efforts and projects of individuals and departments within the organization. Moreover, they cited that market-oriented firms are expected to gather, interpret, and use market information in a more systematic, thoughtful, and anticipatory manner than the less market-oriented firms.

Khaire and Hall (2016) supported this mentioning that many of the business ventures operating in today's world are relying on the concept of market orientation since market orientation has become one of the most significant factors, which the success of the organization highly depends on. To become market-oriented, most small, medium, as well as large scale corporations, have taken steps to invest a large sum of money in modern information systems to acquire the knowledge of customers and competitors. After the acquisition of knowledge, organizations manage the various functions in a coordinated manner towards the accomplishment of goals and objectives set by the top management of firms. He added that in today's world, many factors force business ventures to become market-oriented ever before. Several of those factors are globalization, constantly changing customer needs, wants, and expectations, more empowered customers, and a very competitive business atmosphere.

In addition, Kaleka and Morgan (2019) emphasized that marketing orientation creates strategic intentions such as marketing innovations. The marketing innovations follow the logic of general marketing mix processes (product, price, place, and promotion), include Industry 4.0 technologies like the Internet of Things, and require knowledge-intensive services like Automatization and Artificial Intelligence. Marketing innovation requires skilled labor and mature management to process data as well as information about customers in today's smart digital era. Their preferences underpin the companies' smart marketing innovations, such as mobile applications, information technologies in addition to systems, new ways of delivery, and pricing. The principles of the Marketing Orientation Theory are exhibited in the research study as stated on the different marketing programs, projects, and activities that are being provided by the Department of Trade and Industry (DTI), as an executive department that is tasked as the main economic catalyst that enables innovative, competitive, job-generating, inclusive business.

\subsection{Operational framework}

The following are the independent and dependent variables examined and quantified using the prepared instruments.

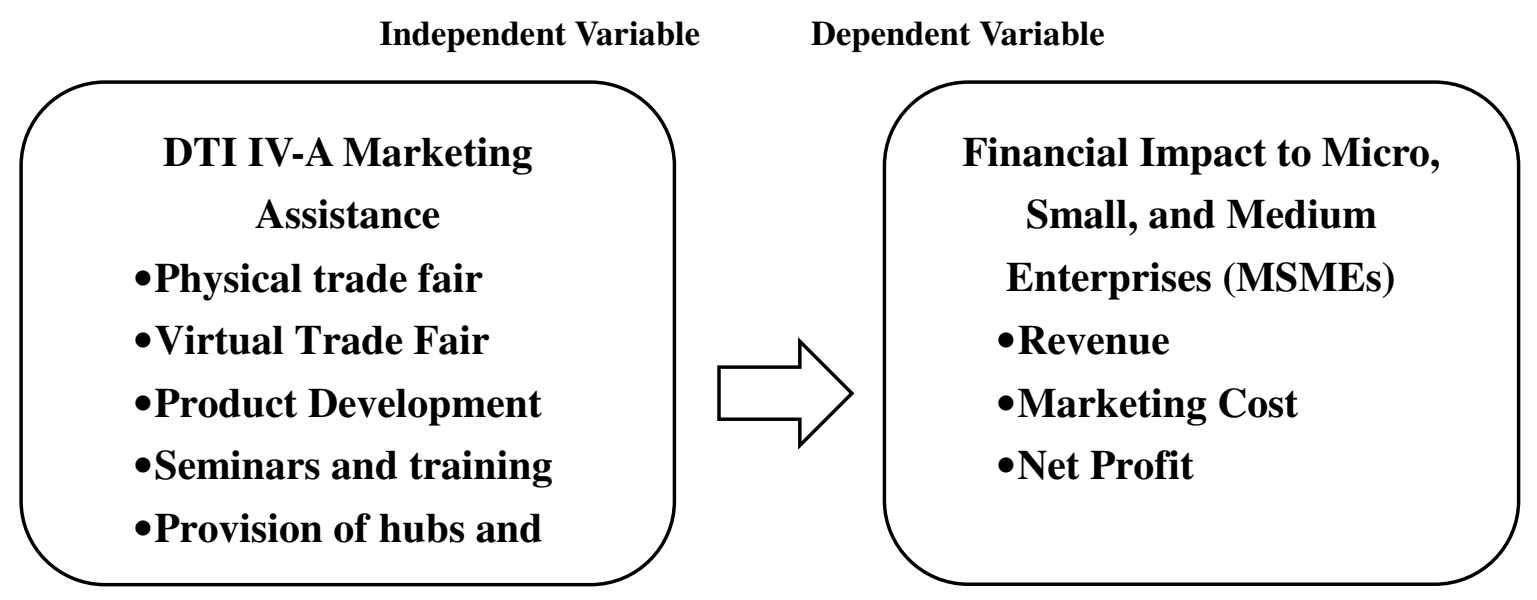

Figure 1. Research Paradigm

The study intended to assess if the Department of Trade and Industry IV-A Marketing Assistance (independent variable) has a relationship to its financial impact of the Micro, Small, and Medium Enterprises

32 Consortia Academia Publishing (A Partner of Tourism Educators and Movers of the Philippines) 
Marketing assistance to micro, small, and medium enterprises and its financial impact: Inputs to marketing plan

(MSMEs) (dependent variable) from the provinces of CALABARZON. Marketing activities are one of the major contributors to the financial status of a business. Figure 1 presents the major concepts of the study. The main focus of the study was to determine if DTI IV-A Marketing Assistance has a financial impact on the Micro, Small, and Medium Enterprises (MSMEs).

\subsection{Statement of the problem}

This study aimed to determine the level of Financial Impact of DTI IV-A Marketing Assistance to Micro, Small, and Medium Enterprises. Specifically, this academic paper sought answers to the following questions:

$>\quad$ What level of marketing assistance does DTI IV-A provide the micro, small, and medium enterprises as assessed by its owners in terms of physical trade fair, virtual trade fair, product development, seminars and training, and provision of hubs and stores?

$>\quad$ What is the level of financial impact of the marketing assistance provided by DTI IV-A in terms of revenue, marketing cost, and net profit?

$>\quad$ Is there a significant relationship between the level of marketing assistance provided by the Department of Trade and Industry and its financial impact on the MSMEs?

$>\quad$ Based on the findings of the study, what enhancement plan may be proposed to improve the current marketing assistance rendered by DTI IV-A?

\subsection{Hypothesis}

The hypothesis that follows was tested at a 0.5 level of significance:

$>$ There is no significant relationship between the level of marketing assistance provided by the Department of Trade and Industry and its level of financial impact on the MSMEs.

\subsection{Scope and delimitations}

The study assessed the extent of Marketing assistance provided by the Department of Trade and Industry IV-A to the Micro, Small, and Medium Enterprises and its financial impact on MSMEs. The marketing assistance covered the physical trade fair, virtual trade fair, product development, seminars and training, and provision of hubs and store as the marketing assistance. The study focused only on the financial impact for the MSMEs as regards revenue, marketing cost, and net profit. The financial impact was the one derived for five (5) years. Restrained by such scope and delimitations, the study was better guided in this research endeavor.

\subsection{Significance of the study}

The following may benefit from the result of the study:

Entrepreneurs. They are the main beneficiaries of this study. The output in coming up with the proposed inputs for the improvement of the current marketing assistance of the Department of Trade and Industry IV-A intends to meet the satisfaction of this group of clients and clientele.

Department of Trade and Industry- Regional Office IV-A (CALABARZON) Trade Promotion Officers. This research may provide a better perspective of the regional offices' performance toward working relationships not only with their personnel but especially with the MSMEs.

MSME Development Council Members. The findings of the study can provide insights to the SMED Council which is responsible for the promotion, growth, and development of SMEs in the country. It facilitates and coordinates national efforts in SME development; thus, the council may find relevant and helpful results that 
will offer ideas as bases to further improve its functions.

Bureau of Domestic Trade Promotion (BDTP) Officers. The study may benefit the BDTP that also handles the Go Lokal Program and National Fairs such as National Food Fair, National Arts and Crafts Fair, and National Trade Fair. This will serve as a reference for local marketing activities.

One Town, One Product (OTOP) Philippines - Project Management Office (PMO) Personnel. The study may also benefit the OTOP-PMO that enables localities and communities to determine, develop, support, and promote products or services that are rooted in its local culture, community resource, creativity, connection, and competitive advantage.

Bureau of Small and Medium Enterprise Development (BSMED) Personnel. The study may also benefit the BSMED. The Bureau is mandated to develop and promote MSMEs in the country by advocating policies, programs, and projects addressing the specific needs of MSMEs in the areas of market access, human resource development, and technology upgrading. Being the SMED Council Secretariat, the Bureau is also tasked to review policy and strategies geared towards MSME development. Hence, the findings of this study are expected to be of help to the bureau.

The Researcher. The findings of the study can provide a better approach to the researcher as the Regional Trade Promotion Officer for Local Marketing concerning the implementation of different marketing assistance that is being provided by the Department of Trade and Industry.

Future Researchers. The study may serve as a reference for other researchers who would want to conduct a similar study. The result can be used in further researches to improve the services rendered by any other offices or establishments.

\section{Background literature}

\subsection{Marketing assistance to micro, small, and medium enterprises}

Bindhu (2020) cited that the Marketing Assistance Scheme focuses on marketing expansion and exposure of MSMEs to the international and domestic market. MSMEs are acting like building blocks in the economic advancement of our country. Thus, the Ministry of MSME is initiating innovative schemes that aid in their enhancement. Accordingly, the said schemes focus on a segment of the sector and provide guidance specifically in that area. He added that marketing plays a key role in the success of an establishment. Thereby, forcing the MSMEs to accept institutional guidance in this area. As opposed to the industries that can hire a group to handle the same. Moreover, Nijssen (2017) emphasized the particular role of marketing. According to him, inexperienced MSMEs with marketing knowledge found it extremely hard to avoid becoming committed to a particular market opportunity early in the process, and thus, found it difficult to come up with several ideas for product applications. In their case, the effect of marketing knowledge did identify many more opportunities than their counterparts without such marketing knowledge.

Furthermore, Golini and Gualandris (2018) highlighted that global economic networks and global value chain companies are the bearers of marketing innovation. Knowledge of these flexible companies includes know-how about institutions and market channels, while every member or contractor is important. Intensifying globalization and the recognition of knowledge in modern economies have led to an uncertain world. Economic leaders and so-called 'go-between leaders' are needed to navigate the global markets. The first one conducts an innovation strategy, while 'go-betweeners' manage the producing and selling strategy. Sustainable production practices are associated with globalization and integration into an enterprise-wide manufacturing network. This means that marketing innovations benefit from product innovation activities.

According to the study of Salazar (2015). Marketing assistance is extended to the small and medium

34 Consortia Academia Publishing (A Partner of Tourism Educators and Movers of the Philippines) 
Marketing assistance to micro, small, and medium enterprises and its financial impact: Inputs to marketing plan

industry sector largely by government institutions. The impact of such assistance, in general, can be gauged from the entrepreneurs' awareness of these existing programs and the agencies carrying them out. Compared with the more direct forms of assistance, (e.g., credit financing), marketing assistance is less commonly known to small and medium entrepreneurs. Only about $29.5 \%$ of entrepreneurs in the regional survey were aware that such forms of assistance existed. Similarly, the research of Bhawann (2019) of the Development Commissioner Ministry of Micro, Small \& Medium Enterprises from India studied the importance of marketing assistance to MSMEs with the subject, Procurement and Marketing Support a component of scheme Development of MSMEs and the study eventually has been approved by the Government of India dated 20 November 2019.

The study stated that marketing is a strategic tool for business development and is critical for the growth and survival of MSMEs. Due to the lack of information, scarcity of resources, and unorganized ways of selling and marketing, the MSME sector often faces problems in exploring new markets and retaining the existing ones. Keeping in view these facts, the Procurement and Marketing Support Scheme has been introduced to enhance the marketability of products and services in the MSME sector. The scheme aims to promote new market access initiatives like organizing and participation in National/International Trade Fairs, Exhibitions, MSME Expo, etc. It also aims to create awareness and educate the MSMEs about the importance, methods, and process of packaging in marketing, latest packaging technology, import-export policy and procedure, GeM portal, MSME Conclave, latest developments in international/national trade, and other subjects or topics relevant for market access developments. And to create more awareness about trade fairs, digital advertising, e-marketing, GST, GeM portal, public procurement policy, and other related topics, etc.

Moreover, Vokoun and Pichova (2020) cited that extended market orientations add factors like culture and test the relationship between market orientation and constructs such as marketing capabilities, enterprise performance, cost leadership strategy, differentiation strategy, and organizational power. Core marketing processes (as marketing capabilities), like product development management, supply chain management, and customer relationship management, are considered factors of an enterprise's market orientation that influence business performance. In addition, Boykin (2019) cited that marketing typically drives revenue rather than the reverse in most successful businesses. Moreover, marketing and advertising spending in most successful businesses is task- or project-oriented. Task-oriented marketing requires a marketing plan, something most marketing experts strongly recommend. The percentage-of-gross-revenue calculation is a useful ballpark gauge of spending parameters. But, the business needs to be flexible depending on the requirements of its marketing plan. It may be able to obtain specific marketing as a percentage of gross revenue figures for your industry trade association.

Furthermore, Knecht (2020) mentioned on Lumitos' Online Marketing Blog that due to canceled or postponed trade fairs brought by the Covid-19 safety restrictions such as lockdowns, the businesses are not getting the all-important sales and virtual trade fair show a way out. It is compact and time-limited and generates many high-quality leads and new customer contact within only a few days. Virtual trade fairs are particularly attractive to reach potential customers that never went to trade fairs even before the pandemic, either because their place of work was too distant, traveling was felt to be too difficult. But especially in these times, virtual trade fairs are the most important instrument for reaching visitors from around the globe. This is because travel restrictions and the enormous costs involved now do indeed prevent visits to on-site trade fairs. It generates a large number of new customer contacts and thus many more business opportunities.

Unusual times such as the current Covid-19 crisis are always an excellent opportunity to stand out from the crowd of competitors and distinguish oneself in terms of innovation. Virtual fairs offer just that. They expand the know-how while they gain valuable experience in offering the company's existing and prospective customers a novel and promising way of getting in touch with them to find out more about their products. There's nothing to lose by participating in a virtual trade fair. The enterprise may gain experience, receive urgently needed sales leads in the shortest of time, strengthen its brand image and gain a competitive edge. It will also be sending a strong and clear signal to its existing and potential customers as well as the employees that will give them 
certainty and guidance.

In terms of brand development, Lath (2018) reiterated that a brand that successfully markets itself is more likely to be a successful brand. Businesses often have a notion that the growth and profit of a business depend completely on the kind of business products/services they offer. But this is not the only factor that determines a business's success. It is the way a company presents its business to the audience. Business performance refers to the qualitative and quantitative progress of the companies in delivering top-quality products, keeping up to their promises, and meeting the expectations of the masses. Moreover, Gotter (2020) said that repeat customer or high customer retention rates increase profitability. A business would want a retention rate to be as high as possible. This not only ensures maximum profitability but lets the business know that its marketing is sound, the quality of the product or service is strong and that the business is targeting the right people or market.

Shamsuddoha and Ndubisi (2019) with the study entitled: Impact of Government Export Assistance on Internationalization of SMEs from developing nations, were found to be in support also of the study because the researcher believed that government assistance should provide financial impact to MSMEs. Research into the internationalization of SMEs has emphasized the role of human capital-related elements of the firm such as managers' attitude and perceptions toward risks and rewards of the international market, their experience, commitment, and strategy that influence the performance of the firms' international activities. These entrepreneurial/managerial resources are in short supply in most SMEs that discourages them to explore international market opportunities. Government assistance programs as an "external change agent" define the premise for successful international activities of the corporate sector and play a key role in stimulating the international business activities of domestic firms.

The empirical findings of this research provide evidence that government export assistance programs play an important role in the SMEs' internationalization process by contributing to several firms and management-related factors that determine the international marketing performance of a firm. Based on the findings, it can be concluded that the use of market development-related assistance programs influences an SME's initial internationalization through export activities directly as well as indirectly through improving managers' perceptions of the overseas market environment and international marketing knowledge. The use of export market development-related assistance such as export market information through trade missions, trade fairs, export workshops and seminars, overseas training programs on product development and marketing helps overcome SME managers' mental barriers and develop positive attitudes toward international marketing activities.

Moreover, Shouk, Zoair, Farrag, and Hewedi (2018) cited in their study entitled: The Role of International Exhibition Venues in Marketing Exhibitors' Destinations analyzed the effect of venue image on the exhibitions' loyalty, and they found that the venue image is a predictor of the visitor or possible market loyalty. They used venue capacity, facilities, cleanliness, accessibility, staff professionalism, service promptness, and venue pleasant design to measure the venue image.

Furthermore, it is cited in the study that they referred to the realistic approach for exhibition venue design as the major focus to create a simulated and realistic experience for visitors. The design includes the appeal of presentation and social interaction among visitors group members. In addition, the venue layout, accessibility, and space provided for visitors in the venue as major facets affecting visitor experience and destination image. The design/layout of the venue should reflect the destination authenticity and deliver a unique image of its attractions. According to them, event design is essential for an event's success on every level; it is a feature of the lived moments of a creative theme. Despite the various types of experience, the design enhances experiences for visitors by engaging, inspiring, educating, and entertaining them. Creating experiences for visitors is linked to the physical environment of the venue. Simply saying, design crates experience, and therefore, the experience could be designed for visitors based on the stakeholders' aims of the event. Add to design, facilities provided at the venue are a crucial component of its success. These facilities include the exhibition facilities, the public 
Marketing assistance to micro, small, and medium enterprises and its financial impact: Inputs to marketing plan

service facilities, food provisions, and the space and size used for the venue. They added that having leisure and entertainment activities in the exhibition increases its competitive advantage and improves the image of the destination.

It is also reiterated in the study of Osei, Shao, Forkuoh, and Osei, A. (2016), The Impact of Institutional Support in SMEs Marketing, and Growth. School of Management and Economics, that the impact of external institutional support on SMEs growth shows a positive correlation between them. As there is ample evidence on the positive impact of external institutional support on SME growth in the UK. In determining the impact of external institutional support on the operations of SMEs in the area of access to external finance, growth, decision marking, managerial training, and capacity building, in all, there was a positive impact on the growth and development of the SMEs. Similarly, the study shows the vital role play by external accountants in the SME sector, which confirms the rationale for an increase in demand for external accountants by SMEs in the area of external support.

Likewise, studies into the effect of trade fairs and exhibitions on firms' performance indicate positive returns in the forms of sales and profit, as research posited that, trade shows and fairs provide positive economic returns to the firms as well as evidence of positive effects on generating product awareness and interest. Trade fairs and exhibitions are not only to be seen as efficient communication and sales tools but also have the tendencies of influencing product and pricing strategies. This was confirmed by Hutt and Speh (2015) stating that the MSMEs should understand the different marketing strategies and drivers of customer profitability. They also cited that business marketing managers can more effectively allocate marketing resources and take action to convert unprofitable relationships into profitable ones.

Moreover, Data Quest India (2019) with article Importance of Learning and Development in Small and Medium Enterprises cited globalization as diverse workforce environment and use of information technology have made organizations enable learning and development as a competitive advantage. In a knowledge-based economy, the collective skills of its employees are critical to business success. Enterprises with a culture of learning are some of the highest performers in competitiveness, agility, and engagement when knowledge is freely distilled throughout the organization. Effective learning has led to greater employee motivation and satisfaction as employees feel keenly valued. This is particularly prevalent in the small-medium sized enterprise (SME) sector where businesses have many of the same needs as multi-national giants, but not the level of resources required to service them. Additionally, as MSMEs begin to fulfill their digital skill gap using technological transformation, advancement in learning and development is making this possible at breakneck speeds and by making learning - 'bite-sized', the attention-span is being captured easily. Overall, this approach helps in making business vital information available at the fingertips of employees. Backed by 'gamification' and 'social learning', they are constantly engaged and retain the 'competitive-spirit'. Locally, the Department of Trade and Industry, as the agency that enables business growth and development in the country, has also been providing various marketing assistance to micro, small and medium enterprises.

Leaño (2017) emphasized the importance of Marketing Assistance to MSMEs. According to her, the Access to Markets (A2M) advantage for MSMEs is to have maintained their existing markets and penetrated new and emerging markets locally and globally. Marketing support systems are established and are sustainably operating. MSMEs are implementing the value chain approach and are benefiting from it. MSMEs are using information technology and intellectual property system to develop a sustainable market share and gain a competitive advantage for their products and services. Market information needed by MSMEs is available and freely accessible. MSMEs have a considerable share in the sustainable development market locally and globally.

The One Town, One Product (OTOP) in the Philippines is a priority stimulus program for Micro, Small and Medium-scale enterprises (MSMEs) as the government's customized intervention to drive inclusive local economic growth. The program enables localities and communities to determine, develop, support, and promote products or services that are rooted in its local culture, community resource, creativity, connection, and 
competitive advantage. As their own 'pride-of-place,' these are offerings where they can be the best at or best renowned for. It endeavors to capacitate our 'OTOPreneurs' to innovate and produce market-ready products and services. (OTOP, n.d.).

In addition, it is an international program that originated from Japan's One Village, One Product. Its various versions and iterations in numerous countries are proof that it is a viable branding and stimulus program for MSMEs. Here in the Philippines, it has been in existence since 2002. This was further powered through the promulgation of Executive Order 176 by then-President Gloria Macapagal-Arroyo in February 2003. After a decade and a half of combined gains and challenges, OTOP remains to be a strategic tool that provides an ecosystem of assistance from local government units, national government agencies, and the private sector. It is now transitioning from a convergent effort to its next phase of execution in the form of OTOP NextGen.

Furthermore, the program has two major components and is generally defined. The first component is OTOP NextGen - as the SUPPLY side of the program; it refers to the package of assistance provided to capacitate the MSMEs. This component is primarily the product development initiatives, training, referral, and others to level up the products in the areas of design, quality, volume, among others. This component addresses mindset changes and mastery of entrepreneurship. And the second component is the OTOP.PH or OTOP Philippines $\mathrm{Hub}$ - as the demand side of the program, this provides the physical and online channels and market access platform where OTOP products - especially those which have been assisted via product development - are showcased on a day-to-day basis. This addresses the market's side of entrepreneurship. Moreover, OTOP Next Gen is DTI's program to level up these products and services. Building from the gains of OTOP first generation, this initiative aims to offer a package of public-private assistance for MSMEs with minimum viable products to come up with new or better offerings with significant improvement and innovation in the areas of quality, product development, design, packaging, standards compliance, marketability, production capability, brand development, among others.

The reboot in 2017 allows communities to have more than one OTOP offering and has transitioned to being more market-oriented and innovation-driven. Market preference ultimately dictates the OTOP offerings and the business direction that OTOPreneurs should take. In its relaunch in 2017, the program was able to assist 6,519 MSMEs and developed or improved a total of 4,960 products and prototypes. Several of these products are now found in supermarkets, weekend bazaars, Go Lokal! outlets, and other market platforms including soon-to-open OTOP.PH or OTOP Philippines Hub. OTOP Philippines Hub or OTOP.PH is a retail store or spaces where products from One Town One Product offerings can be found. Catering to the general mainstream market of both local buyers and tourists, these one-stop-shops offer a general outlet for quality OTOP merchandise before they level up to the premium market catered to by Go Lokal and other high-end markets platforms. As a one-stop-shop, the OTOP Philippines Hub can be a redesigned pasalubong center showcasing mostly OTOP products including OTOP from other regions. The hub can be found mostly in airports, terminals, pasalubong centers, tourist spots, Negosyo Centers, public markets, and other consumer-frequented locations including malls. As another flagship market access program by the Department of Trade and Industry, this serves as a marketing vehicle and incubation platform to promote and champion OTOP products.

Similarly, Thanh (2018), discussed the original concept from Japan, the One Village, One Product (OVOP). It is an approach that has been recently attracted significant attention from many scholars and policymakers as a rural development strategy. This OVOP concept was initially started in Oita Prefecture, Japan, in 1979, by Morihiko Hiramatsu, an idea for regional development policy. The early perception of OVOP was to inspire communities in Oita to selectively producing high-quality added-value goods. The OVOP movement suggested one village produce one competitive and marketable product with regards to their local resources to achieve sales revenue in the market, thus creating income for the residents in the villages and enhancing the local economy.

Likewise, the OVOP approach also inspired local leadership and human resource development at the municipal level by founding several schools for specific training goals. Thanks to the OVOP program, the 
quantity of OVOP goods in Oita enlarged from 143 goods with total values of $\$ 330$ million in 1980 to 336 products with total values of $\$ 1300$ million in 2001 . Throughout that time, the Oita incomes per capita doubled, to which the attainment of the OVOP strategy appears to have contributed. OVOP, from the policymakers' point of view, is useful at bridging the gap between urban and rural areas in developing countries through community-based development. As a result, recently, the OVOP approach has been implemented in many Asian countries and further developing nations, including Africa and Latin America as an alternative economic development path. Additionally, the OVOP movement has become one of the most attractive packages of Japanese ODA (Official Development Assistance) that have a great influence on policymakers.

Another marketing assistance being offered by the department is the Go Lokal! Program. Introduced by the Department of Trade and Industry in collaboration with select retail partners, Go Lokal! is a market access platform provided to the Philippines' micro, small and medium enterprises (MSMEs) for market incubation and brand testing. To date, Go Lokal! has assisted 478 MSMEs spread out in 114 Go Lokal! stores all over the archipelago that offer a wide range of products from finely detailed fashion pieces to top-notch home and food items. More than a hundred of these MSMEs are now regular suppliers of partner retail establishments. Go Lokal! is not just about going local. It is about being multi-local - the appreciation of Philippines traditions, patterns, colors, and style that may be local to us, but exotic to others. It is an excellent marketing avenue provided for free by the DTI and its retail partners for MSME incubation, marketing, and branding. By offering only products of quality, unique design, and compelling narratives, Go Lokal! aims to inspire our entrepreneurs to level up and meet global standards. It is likewise a vehicle to discover emerging suppliers and new products with high market potential. (Go Lokal, n.d).

Furthermore, the program's primary goal is to help the country's MSMEs enter the mainstream market via the free services offered by DTI such as Merchandise development assistance to produce commercially viable products for the market and Market access to stores/spaces provided by Retail Partners such as mall and retail operators. With the need to extend support to the local micro, small, and medium enterprises (MSMEs) affected by the ongoing COVID-19 pandemic, the DTI through its Trade Promotions Group (TPG) led by Usec. Abdulgani Macatoman initiated the Bagsakan Project, a selling activity with a limited number of MSMEs from the different regions, particularly those selling fresh produce and processed foods.

Implemented by the Bureau of Domestic Trade Promotion (BDTP) in cooperation with the DTI-Regional Operations Group, the event is marketed online through the BDTP social media pages, showcasing the participating MSMEs and their products to reach more consumers especially in the National Capital Region (NCR). Orders are taken before the event and confirmed orders are prepared for pick up on the scheduled date. Eventually, in addition to cash-only transactions, digital payments, and bank transfers have provided added convenience to the consumers and MSMEs.

The Department of Trade and Industry (DTI) is offering the Bagsakan Project as part of the DTI's advocacy to "Buy Local, Go Lokal, Shop Local, Eat Local, and Travel Local." In addition, it is also offering various domestic and international trade fairs through the Bureau of Domestic Trade Promotion (BDTP). The mandate of the bureau is to promote the efficient marketing of local products and services through the conduct of marketing events, such as trade fairs, in-store displays, showcases, and local trade missions; expand and strengthening linkages among MSMEs through information exchange and other market matching-related activities; and create awareness of domestic marketing opportunities for new projects, technologies, and investments and to develop and maintain domestic market databases, such as local raw materials suppliers, local semi-processed products suppliers, local finished products suppliers, and buyers (institutional and big buyers). (DTE, n.d.)

There are three (3) major national fairs being conducted annually; the National Trade Fair NTF), National Food Fair (NTF), and National Arts and Crafts Fair (NACF). Every region also has its annual regional trade fairs, with Region IV-A organizing the Kalakal CALABARZON regional trade fair. It has started in 2014 and cooperated with the provincial office; Cavite, Laguna, Batangas, Rizal, and Quezon. The fair is considered as an 
appropriate venue for the CALABARZON MSMEs to promote their products through showcasing and order-taking activities.

The Department of Trade and Industry (DTI) pushed for the adoption of digital strategies and the utilization of e-commerce to assist the recovery of small businesses affected by the COVID-19 pandemic. Indeed, DTI Secretary Ramon M. Lopez commented that "Micro, small, and medium enterprises (MSMEs) need stronger market and financial access to prosper. Our main goal is to not only provide loans and capital but also help MSMEs migrate online through the use of digital platforms in marketing their products,". The Secretary also reiterated that the MSMEs should be protected to save jobs. We must generate income that brings back demand, demand that attracts more production and service activities. This is the way to restart the economy." (DTI. Lopez, 2020, n.d.)

The Department of Trade and Industry (DTI) provides learning and development opportunities through its partnerships with the Philippine Center for Entrepreneurship (PCE) and the Philippine Trade Training Center (PTTC). Amid efforts to expand the country's trade and industry, the need for business professionals trained in promoting international trade further arises. The Kapatid Mentor ME (KMME) Project seeks to assist Micro and Small Enterprises (MSEs) through the provision of mentorship, shared service facilities, and inclusive business models. Training programs provided through the PTTC focus on product and market trends, standards, restrictions, costing and pricing, distribution systems, and other trade-specific concepts.

The Center for International Trade Expositions and Missions (CITEM) is the export promotion arm of the Philippine Department of Trade and Industry (DTI). It is committed to developing, nurturing, and promoting globally competitive small and medium enterprises (SMEs), exporters, designers, and manufacturers by implementing an Integrated Approach to Export Marketing in partnership with other government and private entities. For three decades, CITEM has established the country's image as the premier destination for quality export products and services. It continues to set the highest standards of creativity, excellence, and innovation to achieve export competitiveness in the international market. (CITEM, n.d.)

\subsection{Financial impact of marketing assistance}

Saif (2015) cited that marketing strategy in promotion, pricing, distribution, and product standardization and adaptation have an impact on sales, customer, and financial performance of firms. His study contributes to the existing learning of marketing strategy by supporting a relationship between marketing strategy factors and overall firm performance. The study suggests that the impact is mediated by marketing strategy implementation success.

Terblanche et al. (2015) mentioned that the pressure for financial accountability contributed to widespread concern about the function of marketing within the company. Consequently, marketers have become preoccupied with measuring the performance of marketing activity. Diverse financial and non-financial methods have been developed to provide evidence of how marketing activity impacts the bottom line. In its simplest form, the marketing function serves to manage profitable customer relationships by targeting market segments and tailoring the 4Ps (i.e. product, price, place, and promotion) to meet the needs of the identified target market. They emphasized the importance of the marketing function by stating that the financial success of companies often depends on marketing ability and that the lack thereof could be the Achilles' heel of formerly prosperous companies. It is also stated in the study that they describe marketing as a two-stage process: building brand equity, and then using it to drive cash flow. As a result, if performance is to be benchmarked and monitored, both stages have to be measured. The value of a company is dependent largely on the growth prospects and perceived sustainability of profits. Although a two-stage model like this is theoretically sound, marketers' continual inability to formally trace the effects of a marketing action to company value undermines the latter stage, and in turn, marketing (Rao \& Bharadwaj, 2008; Moorman \& Rust, 1999).

According to Lath (2018), a brand that successfully markets itself is more likely to be a successful brand. 
Businesses often have a notion that the growth and profit of a business depend completely on the kind of business products/services they offer. But this is not the only factor that determines a business's success. It is the way a company presents its business to the audience. Business performance refers to the qualitative and quantitative progress of the companies in delivering top-quality products, keeping up to their promises, and meeting the expectations of the masses. Interestingly, marketing strategy exercises significant control over business performance. It is nothing but the methods and techniques adopted by influential business owners to make their products saleable and appeal to a wider audience. The marketing strategy adopted by a business benefits the overall performance of a company to a great extent.

Lath (2018) added that marketing for small and medium-sized enterprises seems to be quite a daunting task, but if done the right way can generate more profit. A well-defined marketing strategy leads to an increase in business sales and marketing. This directly impacts the revenue generated as the company reaches out to people, the more it reaches out to its business or brand. The marketing of a business is directly related to the sales it generates. While defining the marketing strategy, the business should also estimate how much of an increase in revenue or sales it expects the strategy to bring about. Markgraf (2019) stated that companies develop marketing strategies to help develop brand identities, increase sales and gain market share. Strategic approaches include an emphasis on promotional tools available to marketing specialists, and the use of such tools has an impact on company performance. The focus of a market strategy is on the effects of specific elements and how they affect a company's position in the marketplace. An understanding of how the tools and strategic elements work helps businesses implement market strategies that increase profits.

Porto, Costa, and Watanabe (2017) demonstrated in their study the effectiveness of marketing activities in dynamically generated product sales, revenue, and profitability in a microenterprise. They mentioned that if the micro-enterprise maintains its operations over time, it is because the marketing activities carried out to generate a minimally positive effect on product sales. Activities that are typically carried out by small enterprises focus on day-to-day business. At the same time, these marketing activities, in an aggregated way, dynamically alter the financial consequence for the company by positively affecting revenue, and, also profit. Pyle (2020) cited that one of the simplest and most effective ways for marketing to directly impact revenue is to focus on sales enablement. Essentially, sales enablement is equipping the business development team with assets that make them more efficient and effective. This includes content that helps prospects to answer the questions they ask, solve their problems, and build the case internally with their team. The best thing about sales enablement is that it can be tracked, measured, and attributed to the bottom line.

The most effective sales-enablement tools proactively answer the questions of prospective customers. This includes assets such as answers to frequently asked questions, at-a-glance competitor comparisons, and statistics that add credibility. To add, sales enablement comes in different formats. Every customer is different in how they prefer to consume content. Re-organizing the content created into various formats is one of the simplest ways to maximize content marketing efforts. Equipping the sales team with content in various formats such as e-books, case studies, blog posts, videos, webinars, and infographics is key.

According to De Martini (2017), to be successful, marketing operations must align their goals with those of the marketing function, which, in turn, should be aligned with the sales objectives and organizational objectives. If the organization's objectives include growing revenue, marketing operations must also learn how to contribute to revenue growth. Marketing operations play an important role in driving the marketing strategy to fruition and partnering with sales to contribute to revenue attainment. Marketing operations can take three actions immediately to increase ROI for the business and better enable sales: Align campaigns to support the business; Perform touch analysis and repeat patterns of success, and Develop an effective data strategy. Using the key focus areas of marketing operations functions, including planning, measurement, and data management, marketing operations can enable sales and the business to achieve its goals.

Willis (2015) cited that the marketing role as a revenue-generating engine is about awareness: brand 
awareness, demand generation, and outreach. The purpose of marketing is about making noise and allowing the market to find out about the market they are targeting. Bottom line, there is no way to generate demand for the product or service without marketing. In addition, marketing plays a very strategic role in educating the marketplace. This is especially common in the startup world and key to the success of new companies. This organization is fascinating and is creating an entirely new industry that has never existed before so educating the world on what they do is key in selling products and services.

Gillum (2015) mentioned the three (3) key insights on the importance of marketing and how it was impacting the company's sales success. First, the company can increase opportunities with the help of marketing. The company can increase the marketing budget and reallocate funds from events into digital marketing. Second, increased marketing activity can create the perception of greater sales coverage. Buyers perceived an increase in visits despite the fact that the number of representatives in the segment remained the same over a long time. Third, marketing can identify shifts in buying behavior.

Locally, a press release on the DTI website mentioned that the agency through its financing arm, the Small Business Corporation (SBCorp) has approved, as of 9 February 2021, a total of 21,695 loan applications under the Bayanihan COVID-19 Assistance to Restart Enterprises (CARES) program to provide micro, small, and medium enterprises (MSME) with urgent relief needed to restart their businesses amid the pandemic. Under the Republic Act No. 11494 or the "Bayanihan to Recover as One Act" (BAYANIHAN 2), financial support amounting to $\mathrm{P} 10 \mathrm{~B}$ has been allotted to the CARES program to help mitigate the adverse impact of the pandemic on MSMEs. Lopez (2020) reiterated the agency's efforts to provide relief and assistance to MSMEs through the CARES program are further strengthened, especially as the agency work towards the sustainable and inclusive recovery of the nation. Over 20,000 MSMEs have already benefitted from the loan portfolio, which has helped businesses survive from permanent closure, recover from the effects of the pandemic, save or even create more jobs, and provide income to millions of Filipinos and their families.

\subsection{Gaps bridged by the study}

After the review of varied literature, this study is expected to fill in gaps. The study identified the marketing assistance by the government such as the virtual trade fair, product development, and seminars and training which have not been indicated in the conducted readings. While in the reviewed literature included was international marketing assistance, physical trade fair, and provision of hubs and stores the study indicated it on the other hand, in the indicators under all the sub-variables of the marketing assistance being provided by the Department of Trade and Industry. No reviewed literature mentioned marketing costs affected by the marketing assistance. The study had the said concept among the criteria in finding the level of financial impact of marketing assistance.

\section{Method}

Research Design - This study is quantitative research that used the descriptive correlation method of research. Descriptive research can be explained as a statement of affairs as they are at present with the researcher having no control over variables. Moreover, descriptive research may be characterized as simply the attempt to determine, describe or identify what is, while analytical research attempts to establish why it is that way or how it came to be. Descriptive research is aimed at casting light on current issues or problems through a process of data collection that enables them to describe the situation more completely than was possible without employing this method. In its essence, descriptive studies are used to describe various aspects of the phenomenon. In its popular format, descriptive research is used to describe the characteristics and/or behavior of the sample population. The descriptive correlation measures the relationship between two or more variables, gives an indication of how one variable may predict another (McCombes, 2020).

In this study the two (2) main variables are DTI marketing assistance such as physical trade fair, virtual 
Marketing assistance to micro, small, and medium enterprises and its financial impact: Inputs to marketing plan

trade fair, product development, seminars and training, and provision of hubs and stores and its financial impact to MSMEs in terms of revenue, marketing cost, and net profit. The physical trade fair refers to an exhibition organized so that companies in a specific industry can showcase and demonstrate their latest products and services, meet with industry partners and customers. While the virtual trade fair is an online version of an event at which goods and services for a specific industry are exhibited and demonstrated. In addition, product development refers to the creation of a new product that has some utility; or up-gradation of the existing product; or enhancement of the production process, method, or system. Finally, seminars and training is a program where attendees are given information about a specific topic. Moreover, provision of hubs and stores refers to DTI's delivery of an effective center of an activity, region, or network.

On the other hand, the revenue is the income generated from normal business operations and includes discounts and deductions for returned merchandise. While, market cost means the expenses that the company makes to market and sell its products and develop and promote its brand. These marketing costs or expenses include expenses incurred to change the title of goods, promotion of goods, inventory costs, and distribution of goods. And net profit is the measurement of a company's profit once operating costs, taxes, interest, and depreciation have all been subtracted from its total revenues.

Research Locale - The data were gathered from the selected Micro, Small, and Medium Enterprises in all the provinces of Region IV-A: CALABARZON; Cavite, Laguna, Batangas, Rizal, and Quezon. The researcher opted to conduct the study in all the provinces of Region IV-A as she is reporting to the Department of Trade and Industry Regional Office IV-A, hence she has access to all the respondents.

Population and Sampling - There are five (5) DTI Provincial Offices in the five (5) provinces of CALABARZON under the DTI Regional Office IV-A with a total of approximately 18,000 assisted micro, small, and medium enterprises. The population of MSMEs consist of the following enterprise scale: Approximately, there are 15,000 micro-enterprises and 180 of them are beneficiaries of different marketing activities; 2,750 small enterprises and 300 of them are beneficiaries of different marketing activities; 250 medium enterprises and 75 of them are beneficiaries of different marketing activities. Creswell (2018) mentioned that in a quantitative approach, a target population (or sampling frame) is a group of individuals with some common defining characteristics that the researcher can identify and study. Furthermore, Johnson and Shoulders (2019) cited the $\mathrm{G}^{*}$ Power application software that was introduced by Faul, Erdfelder, Lang, ND Buchner for Statistical Analyses in the domain of correlation and regression analyses is useful in identifying the sample population. In this form, the study utilized the $\mathrm{G}^{*}$ Power application software in determining the 228 sample respondent with additional 24 respondents that served as buffer to obtain the precision of estimates and the power of the study to draw conclusions. In total there are 252 sample respondents which are $45 \%$ of the total population.

Respondents of the Study - The study utilized respondents from the five (5) provinces of Region IV-A: CALABARZON. Likewise, there were three (3) groups of respondents in the study, micro-enterprises, small enterprises, and medium enterprises business owners. The Department of Trade and Industry - Regional Office IV-A has a total of 555 MSME-beneficiaries of Marketing Assistance from all the provinces of CALABARZON. It is comprised of 180 micro-enterprises, 300 small enterprises, and 75 medium enterprises. Using G* Power application software, the computed sample size was 82 out of 180 micro enterprises, 136 out of 300 small enterprises, and 34 out of 75 medium enterprises.

Instrument - A researcher-made survey instrument was utilized to answer the formulated question on the financial impact of DTI IV-A marketing assistance to micro, small, and medium enterprises (MSMEs). The first part dealt with the level of DTI IV-A marketing assistance that was based on five (5) variables - physical trade fair, virtual trade fair, product development, seminars and training, and provision of hubs and stores. For easy administration, scoring, and assessment of the survey questionnaire, the Likert scale was utilized to easily obtain the responses. The four (4) point scale is ranging from four (4) being the highest and one (1) as the lowest. Scales used are as follows: 4 or very high $=3.26-4.00,3$ or high $=2.51-3.25,2$ or low $=1.76-2.50$, and 1 or very 
low $=1.00-1.75$.

Validation of the Instrument - The validation of the survey questionnaire was completed through the assistance of the research experts (research adviser, MBA Chairman, MBA professor, and statistician) to establish content and construct validity. The DTI provincial trade promotion officers were also consulted to check the clarity and validity of the questions. The questionnaire went through several editing during its validation period. When the consequent corrections and suggestions were incorporated, the initial draft of the questionnaire was prepared. The Cronbach's Alpha was used to measure the reliability of the survey instrument to find out the extent to which the scale to be used in the statistical treatment would produce a consistent result. There were ten (10) respondents who answered the pilot testing and then after getting the result, the final draft of the questionnaire was readied, and consequently, was administered to the respondents of the study.

Data Gathering Procedure - In the conduct of this study, certain procedures were followed. The related literature and studies were gathered which formed the source for the formulation of the survey questionnaire. Before the actual data gathering, a letter of request was prepared for the consent of the DTI IV-A Regional Director. Letters for the cooperation and permission of the respondents were also prepared. After the approval, the researcher distributed the survey questionnaire online with the use of Google Form to the micro, small, and medium enterprises via electronic communications such as email, Viber, and Facebook Messenger applications, for safety protocol compliance due to the Covid-19 pandemic. The Institutional Statistician's advice and assistance were-sought to tabulate, analyze and interpret the data collected.

Ethical Considerations - The ethical guidelines as specified in the Research Manual of the school were followed as those ethical considerations had been taken into account throughout the study. The consent of the respondents for the survey questionnaire was sought explaining to them the importance/ significance and objectives of the study. The data and information that were gathered were kept confidential. The works of researchers of other authors were also properly recognized. For this study which intended to look at the level of marketing assistance provided to the MSMEs, no question that could offend the MSMEs were included. Likewise, the questions were prepared in such a manner that there was no judgment or any mention of any specific practices or beliefs.

Treatment of Quantitative Data - The following were the statistical treatments applied in the study by the statistician. The mean and the four-point Likert Scale were used to determine the level of DTI IV-A marketing assistance to the micro, small, and medium enterprises in all the provinces of Region IV-A: CALABARZON. The mean and the four-point Likert Scale were also used to determine the level of financial impact of the marketing assistance provided by DTI IV-A to the MSMEs. The Pearson's R Product-Moment Correlation was used to establish the significant relationship between the level of marketing assistance provided by the Department of Trade and Industry as reflected on its financial impact on the MSMEs.

\section{Results and findings}

Table 1.1 shows the level of DTI IV-A marketing assistance being provided to the micro, small, and medium enterprises as assessed by its owners in terms of the physical trade fair. This generates a general composite mean of $\mathbf{3 . 5 4}$ and is interpreted as Very High. The indicator Provides an appropriate venue for MSMEs to advertise their products has the highest mean which is $\mathbf{3 . 7 0}$ interpreted as Very High. Meanwhile, the indicator Assists the MSMEs to generate jobs has the least mean of $\mathbf{3 . 3 5}$ and interpreted as Very High.

The results imply that DTI IV-A has been providing appropriate venues for the conduct of various physical trade fairs. The office has been undergoing planning sessions for the upcoming physical trade fairs and monitoring and evaluation process of the previous venues for the selection of a location of a forthcoming trade fair for the possibility of higher sales generation, larger foot traffic, and new market acquisition. On the other hand, job generation only takes place when there is a significant increase and fluctuation of production due to additional demand or season. 
Marketing assistance to micro, small, and medium enterprises and its financial impact: Inputs to marketing plan

Table 1.1

Level of DTI IV-A marketing assistance as assessed by its owners in terms of on physical trade fair

\begin{tabular}{|c|c|c|}
\hline $\begin{array}{c}\text { Indicators } \\
\text { The Department of Trade and Industry on Physical Trade Fair }\end{array}$ & M & VI \\
\hline 1. Provides an appropriate venue for msmes to advertise their products. & 3.70 & $\mathrm{VH}$ \\
\hline $\begin{array}{l}\text { 2. Provides opportunities to highlight the newly-developed products of the } \\
\text { participating msmes. }\end{array}$ & 3.45 & $\mathrm{VH}$ \\
\hline 3. Provides msmes' customers the chance to ask about their products. & 3.63 & VH \\
\hline $\begin{array}{l}\text { 4. Assists the msmes to have a setting for buyers to check and touch the products } \\
\text { they are interested to buy. }\end{array}$ & 3.57 & $\mathrm{VH}$ \\
\hline 5. Assists msmes to generate jobs. & 3.35 & $\mathrm{VH}$ \\
\hline General Assessment & 3.54 & $\mathrm{VH}$ \\
\hline
\end{tabular}

In relation to this, Shamsuddoha \& Ndubisi (2019) mentioned in the study entitled: Impact of Government Export Assistance on Internationalization of SMEs from developing nations that trade fairs and exhibitions on firms indicates a positive return in the forms of sales and profit. Moreover, Shouk, Zoair, Farrag, and Hewedi (2018) cited in their study entitled: The Role of International Exhibition Venues in Marketing Exhibitors' Destinations analyzed the effect of venue image on the exhibitions' loyalty, and they found that the venue image is a predictor of the visitor or possible market loyalty. They used venue capacity, facilities, cleanliness, accessibility, staff professionalism, service promptness, and venue pleasant design to measure the venue image. Furthermore, it is cited in the study that the realistic approach for exhibition venue design is the major focus to create a simulated and realistic experience for visitors. The design includes the appeal of presentation and social interaction among visitors group members. In addition, they referred to the venue layout, accessibility, and space provided for visitors in the venue as major facets affecting visitor experience and destination image. The design/layout of the venue should reflect the destination authenticity and deliver a unique image of its attractions.

According to them, event design is essential for an event's success on every level; it is a feature of the lived moments of a creative theme. Despite the various types of experience, the design enhances experiences for visitors by engaging, inspiring, educating, and entertaining them. Creating experiences for visitors is linked to the physical environment of the venue. Simply saying, design crates experience, and therefore, the experience could be designed for visitors based on the stakeholders' aims of the event. Add to design, facilities provided at the venue are a crucial component of its success. These facilities include the exhibition facilities, the public service facilities, food provisions, and the space and size used for the venue. They added that having leisure and entertainment activities in the exhibition increases its competitive advantage and improves the image of the destination.

\section{Table 1.2}

Level of DTI IV-A marketing assistance as assessed by its owners in terms of virtual trade fair

\begin{tabular}{|c|c|c|}
\hline $\begin{array}{c}\text { Indicators } \\
\text { The Department of Trade and Industry on Virtual Trade Fair }\end{array}$ & M & VI \\
\hline 1. Offers the chance to link-local msmes producers with buyers through digital means. & 3.58 & VH \\
\hline $\begin{array}{l}\text { 2. Encourages the msmes to upload on the virtual platforms their product photos for } \\
\text { interested buyers. }\end{array}$ & 3.60 & VH \\
\hline 3. Provides virtual negotiation between seller-exhibitor and buyer. & 3.36 & VH \\
\hline 4. Motivates the msmes for a better way of doing business through digitalization. & 3.60 & $\mathrm{VH}$ \\
\hline 5. Offers live selling. & 3.23 & $\mathrm{H}$ \\
\hline $\begin{array}{l}\text { 6. Inspires msmes to be virtually competitive with other products both locally and } \\
\text { globally. }\end{array}$ & 3.61 & $\mathrm{VH}$ \\
\hline 7. Enables buyers to visit the booths without going out to the physical venue. & 3.56 & VH \\
\hline 8. Encourages the utilization of e-commerce to assist the recovery of small businesses & 3.55 & $\mathrm{VH}$ \\
\hline General Assessment & 3.51 & VH \\
\hline
\end{tabular}


Table 2.2 shows the level of DTI IV-A marketing assistance being provided to the micro, small, and medium enterprises as assessed by its owners in terms of the virtual trade fair. The general composite mean is 3.51 and is interpreted as Very High. The indicator Inspires MSMEs to be virtually competitive with other products both locally and globally has the highest mean which is $\mathbf{3 . 6 1}$ interpreted as Very High. Meanwhile, the indicator Offers live selling has the least mean of $\mathbf{3 . 2 3}$ and is interpreted as High.

This indicates that DTI IV-A is doing its best in motivating and urging the micro, small, and medium enterprises to go online given the current onset worldwide. The utilization of E-commerce, which started in 1994, has been introduced years ago to the CALABARZON MSMEs and reinforced last year (2020) due to the new normal brought by the pandemic. Live selling on the other hand is being recognized and utilized only by MSMEs that have a stable internet connection and with staff that is technically inclined with the platform being used.

In support of this, as stated on the DTI website, the Department of Trade and Industry (DTI) pushed for the adoption of digital strategies and utilization of e-commerce to assist the recovery of small businesses affected by the COVID-19 pandemic. Indeed, DTI Secretary Ramon M. Lopez commented that "Micro, small, and medium enterprises (MSMEs) need stronger market and financial access to prosper. Our main goal is to not only provide loans and capital but also help MSMEs migrate online through the use of digital platforms in marketing their products,". The Secretary reiterated: "We must save MSMEs to save jobs. We must generate income that brings back demand, demand that attracts more production and service activities. This is the way to restart the economy.” (DTI. Lopez, 2020, n.d.)

Furthermore, Knecht (2020) mentioned on Lumitos' Online Marketing Blog that due to canceled or postponed trade fairs brought by the Covid-19 safety restrictions such as lockdowns, the businesses are not getting the all-important sales and virtual trade fair show a way out. It is compact and time-limited and generates many high-quality leads and new customer contact within only a few days. Virtual trade fairs are particularly attractive to reach potential customers that never went to trade fairs even before the pandemic, either because their place of work was too distant, traveling was felt to be too difficult. But especially in these times, virtual trade fairs are the most important instrument for reaching visitors from around the globe. This is because travel restrictions and the enormous costs involved now do indeed prevent visits to on-site trade fairs. It generates a large number of new customer contacts and thus many more business opportunities.

Unusual times such as the current Covid-19 crisis are always an excellent opportunity to stand out from the crowd of competitors and distinguish oneself in terms of innovation. Virtual fairs offer just that. They expand the know-how while they gain valuable experience in offering the company's existing and prospective customers a novel and promising way of getting in touch with them to find out more about their products. There's nothing to lose by participating in a virtual trade fair. The enterprise may gain experience, receive urgently needed sales leads in the shortest of time, strengthen its brand image and gain a competitive edge. It will also be sending a strong and clear signal to its existing and potential customers as well as the employees that will give them certainty and guidance.

Table 1.3 shows the level of DTI IV-A marketing assistance being provided to the micro, small, and medium enterprises as assessed by its owners in terms of product development. The general composite mean is $\mathbf{3 . 5 4}$ and is interpreted as Very High. The indicator Assists the MSMEs in leveling up the products in the areas of design and quality has the highest mean which is $\mathbf{3 . 6 3}$ interpreted as Very High. Meanwhile, the indicator Extends assistance to MSMEs' brand development has the least mean of $\mathbf{3 . 4 0}$ and is interpreted as Very High.

The outcomes indicate that the DTI IV-A is of continuous assistance to entrepreneurs in taking their products to the next level. This includes hiring professionals such as designers and graphic artists for product upgrades and obtaining a pool of well-known, entrepreneurial speakers and mentors for SMEs' advancement of skills and knowledge. These actions are just some of the One Town, One Product (OTOP) program's assistance. On the other hand, brand development requires a financial commitment with the business as it needs certification from 
Marketing assistance to micro, small, and medium enterprises and its financial impact: Inputs to marketing plan the Intellectual Property Office of the Philippines. (IPO Phil).

\section{Table 1.3}

Level of DTI IV-A marketing assistance as assessed by its owners in terms of on product development

\begin{tabular}{|c|c|c|}
\hline $\begin{array}{c}\text { Indicators } \\
\text { The Department of Trade and Industry on Product Development }\end{array}$ & M & VI \\
\hline 1. Intensifies its efforts in helping enterprises in terms of packaging their products. & 3.57 & $\mathrm{VH}$ \\
\hline $\begin{array}{l}\text { 2. Urges msmes to take advantage of the programs and services of DTI for their } \\
\text { products to become more competitive in the global market. }\end{array}$ & 3.50 & VH \\
\hline 3. Helps the msmes in elevating the standards of their products. & 3.60 & VH \\
\hline 4. Extends assistance to msmes' brand development. & 3.40 & $\mathrm{VH}$ \\
\hline 5. Assists the msmes in leveling up the products in the areas of design and quality. & 3.63 & $\mathrm{VH}$ \\
\hline $\begin{array}{l}\text { 6. Continues the highest standards of innovation to achieve msmes competitiveness in } \\
\text { the international market. }\end{array}$ & 3.47 & VH \\
\hline $\begin{array}{l}\text { 7. Supports programs and services tailored to address the product design needs of the } \\
\text { msmes. }\end{array}$ & 3.59 & VH \\
\hline $\begin{array}{l}\text { 8. Hires professional designers to discuss current market trends in packaging and } \\
\text { labeling. }\end{array}$ & 3.51 & VH \\
\hline $\begin{array}{l}\text { 9. Requires the Design Center of the Philippines and hired professional designers to } \\
\text { hold one-on-one consultations wherein msmes are given the opportunity to ask } \\
\text { technical questions as regards product development. }\end{array}$ & 3.56 & VH \\
\hline $\begin{array}{l}\text { 10. Stresses the importance of providing consistent product development for local } \\
\text { msmes-producers. }\end{array}$ & 3.58 & VH \\
\hline General Assessment & 3.54 & $\mathrm{VH}$ \\
\hline
\end{tabular}

As stated on the DTI website, the One Town, One Product (OTOP) Philippines is a priority stimulus program for Micro, Small and Medium-scale enterprises (MSMEs) as the government's customized intervention to drive inclusive local economic growth. The program enables localities and communities to determine, develop, support, and promote products or services that are rooted in its local culture, community resource, creativity, connection, and competitive advantage. As their own 'pride-of-place,' these are offerings where they can be the best at or best renowned for. It endeavors to capacitate our 'OTOPreneurs' to innovate and produce market-ready products and services.

The program has two major components and is generally defined. The first component is OTOP NextGen as the SUPPLY side of the program; it refers to the package of assistance provided to capacitate the MSMEs. This component is primarily the product development initiatives, training, referral, and others with the goal of leveling up the products in the areas of design, quality, volume, among others. This component addresses mindset changes and mastery of entrepreneurship. And the second component is the OTOP.PH or OTOP Philippines Hub - as the demand side of the program, this provides the physical and online channels and market access platform where OTOP products - especially those which have been assisted via product development are showcased on a day-to-day basis. This addresses the market's side of entrepreneurship.

To support this, Mellor (2019) cited that product development is the lifeblood of companies and societies. The first and most important reason for any new development is to provide new value to the customer. Without this, there is no reason for the buyer to trade their money for the new device. However, if the product or service offers overwhelming value, then customers will flock to it. This new and increasing value is what keeps companies growing. If there is no new value to offer customers, the firm wilts and eventually dies. If the value offered is not increasing, then the company is losing ground in the market as its competitors increase their value in the market. Many new products are simply an incremental improvement over the previous version with only some new features or slightly faster performance. These products may sustain the company by offering enough new value to generate additional revenue. There are certain instances where new products will improve society beyond just the immediate gratification of the consumer. The new products and services created and provided by companies of all sizes provide the mechanism for this growth and improvement. 
In terms of brand development, Lath (2018) reiterated that a brand that successfully markets itself is more likely to be a successful brand. Businesses often have a notion that the growth and profit of a business depend completely on the kind of business products/services they offer. But this is not the only factor that determines a business's success. It is the way a company presents its business to the audience. Business performance refers to the qualitative and quantitative progress of the companies in delivering top-quality products, keeping up to their promises, and meeting the expectations of the masses.

Table 2.4 shows the level of DTI IV-A marketing assistance being provided to the micro, small, and medium enterprises as assessed by its owners in terms of seminars and training. The general composite mean is $\mathbf{3 . 5 7}$ and is interpreted as Very High. The indicator Provides free online Entrepreneurial seminars has the highest mean which is 3.67 interpreted as Very High. On the other hand, the indicator Conducts financial literacy fora has the least mean of $\mathbf{3 . 4 0}$ and is interpreted as Very High.

\section{Table 1.4}

Level of DTI IV-A marketing assistance as assessed by its owners in terms of seminars and training

\begin{tabular}{|c|c|c|}
\hline $\begin{array}{c}\text { Indicators } \\
\text { The Department of Trade and Industry on Seminars and Training }\end{array}$ & M & VI \\
\hline $\begin{array}{l}\text { 1. Taps well-known business educators and successful entrepreneurs as } \\
\text { speakers/resource persons for seminars offered to msmes for free. }\end{array}$ & 3.62 & $\mathrm{VH}$ \\
\hline 2. Promotes inclusive growth through regular seminars and training for msmes. & 3.63 & VH \\
\hline $\begin{array}{l}\text { 3. Commits to assisting msmes in advancing their skills through capacity-building } \\
\text { programs. }\end{array}$ & 3.61 & $\mathrm{VH}$ \\
\hline $\begin{array}{l}\text { 4. Pledges to be at the forefront of equipping growth-oriented msmes for nationally } \\
\text { and internationally aligned businesses. }\end{array}$ & 3.57 & $\mathrm{VH}$ \\
\hline 5. Provides free online Entrepreneurial seminars. & 3.67 & $\mathrm{VH}$ \\
\hline 6. Conducts financial literacy fora. & 3.40 & VH \\
\hline 7. Offers training courses on e-marketing tools. & 3.54 & VH \\
\hline General Assessment & 3.57 & VH \\
\hline
\end{tabular}

The results prove that DTI IV-A is committed to assist the MSMEs in advancing their skills and competencies through comprehensive training and capacity-building programs on trade-related matters to succeed locally and internationally. Nowadays, digital skill gaps using technological transformation training are also being provided to the MSMEs due to online platforms utilization for selling products. Furthermore, due to the consequences of the Covid-19 pandemic, MSMEs have become vulnerable thus, their eagerness to attend more financial literacy forums for assistance.

As stated on the DTI website, the Department of Trade and Industry (DTI) provides learning and development opportunities through its partnerships with the Philippine Trade Training Center (PTTC) and the Philippine Center for Entrepreneurship (PCE). Amid efforts to expand the country's trade and industry, the need for business professionals trained in promoting international trade further arises. The One Town, One Product Philippines (OTOP), as well as the Kapatid Mentor ME (KMME) and SME Roving Academy (SMERA) thru Negosyo Centers (NCs) seek to assist Micro and Small Enterprises (MSEs) through the provision of mentorship, shared service facilities, and inclusive business models. Training programs provided through the PTTC focus on product and market trends, standards, restrictions, costing and pricing, distribution systems, and other trade-specific concepts.

It is supported by Data Quest India (2019) with article Importance of Learning and Development in Small and Medium Enterprises that cited globalization as diverse workforce environment and use of information technology have made organizations enable learning and development as a competitive advantage. In a knowledge-based economy, the collective skills of its employees are critical to business success. Enterprises with a culture of learning are some of the highest performers in competitiveness, agility, and engagement when knowledge is freely distilled throughout the organization. Effective learning has led to greater employee motivation and satisfaction as employees feel keenly valued. This is particularly prevalent in the small-medium 
Marketing assistance to micro, small, and medium enterprises and its financial impact: Inputs to marketing plan

sized enterprise (SME) sector where businesses have many of the same needs as multi-national giants, but not the level of resources required to service them. Additionally, as MSMEs begin to fulfill their digital skill gap using technological transformation, advancement in learning and development is making this possible at breakneck speeds and by making learning - 'bite-sized', the attention-span is being captured easily. Overall, this approach helps in making business vital information available at the fingertips of employees. Backed by 'gamification' and 'social learning', they are constantly engaged and retain the 'competitive-spirit'.

As regards financial literacy fora, a press release on the DTI website mentioned that the agency through its financing arm, the Small Business Corporation (SBCorp) has approved, as of 9 February 2021, a total of 21,695 loan applications under the Bayanihan COVID-19 Assistance to Restart Enterprises (CARES) program to provide micro, small, and medium enterprises (MSME) with urgent relief needed to restart their businesses amid the pandemic. Under the Republic Act No. 11494 or the "Bayanihan to Recover as One Act" (BAYANIHAN 2), financial support amounting to $\mathrm{P} 10 \mathrm{~B}$ has been allotted to the CARES program to help mitigate the adverse impact of the pandemic on MSMEs. Lopez (2020) reiterated the agency's efforts to provide relief and assistance to MSMEs through the CARES program are further strengthened, especially as the agency work towards the sustainable and inclusive recovery of the nation. Over 20,000 MSMEs have already benefitted from the loan portfolio, which has helped businesses survive from permanent closure, recover from the effects of the pandemic, save or even create more jobs, and provide income to millions of Filipinos and their families.

Table 2.5 shows the level of DTI IV-A marketing assistance being provided to the micro, small, and medium enterprises as assessed by its owners in terms of provision of hubs and stores. The general composite mean is 3.46 and is interpreted as Very High. The indicator Enables MSMEs to support a product or service that is rooted in its local culture has the highest mean which is $\mathbf{3 . 6 0}$ interpreted as Very High. On the other hand, the indicator Considers the establishment of hubs and stores as innovation centers - essentially internet-enabled venues for collaboration of technopreneurs has the least mean of $\mathbf{3 . 3 0}$ and is interpreted as Very High.

\section{Table 1.5}

Level of DTI IV-A marketing assistance as assessed by its owners in terms of provision of hubs and stores

\begin{tabular}{|c|c|c|}
\hline $\begin{array}{c}\text { Indicators } \\
\text { The Department of Trade and Industry on Provision of Hubs and Stores }\end{array}$ & M & VI \\
\hline 1. Provides the co-working spaces to technology-based msmes. & 3.41 & $\mathrm{VH}$ \\
\hline 2. Enables msmes to support product or service that is rooted in its local culture. & 3.60 & VH \\
\hline 3. Establishes hubs and stores to serve as outlets for msmes to have resellers. & 3.42 & $\mathrm{VH}$ \\
\hline 4. Provides hubs and stores to host quality products of msmes. & 3.56 & $\mathrm{VH}$ \\
\hline 5. Considers the establishment of hubs and stores as innovation centers - essentially & 3.30 & $\mathrm{VH}$ \\
\hline General Assessment & 3.46 & $\mathrm{VH}$ \\
\hline
\end{tabular}

The results imply that DTI IV-A has been providing hubs and stores such as the OTOP and Go Lokal stores that aim to promote goods and products of Filipino towns, cities, and regions. This is a big help to local entrepreneurs, especially that the hubs and stores are located not only in the MSMEs' location but also in different regions giving other provinces the taste and feel of one town's local delicacies and handicrafts.

On the other note, internet-based venues are still dispensable to some MSMEs due to their locations' internet connection stability and technology know-how. It is mentioned on the DTI website that the One Town, One Product (OTOP) Philippines is a priority stimulus program for Micro, Small and Medium-scale enterprises (MSMEs) as the government's customized intervention to drive inclusive local economic growth. The program enables localities and communities to determine, develop, support, and promote products or services that are rooted in its local culture, community resource, creativity, connection, and competitive advantage. As their own 'pride-of-place,' these are offerings where they can be the best at or best renowned for. It endeavors to capacitate our 'OTOPreneurs' to innovate and produce market-ready products and services. (OTOP, n.d.).

Similarly, Thanh (2018), discussed the original concept from Japan, the One Village, One Product (OVOP). 
It is an approach that has been recently attracted significant attention from many scholars and policymakers as a rural development strategy. This OVOP concept was initially started in Oita Prefecture, Japan, in 1979, by Morihiko Hiramatsu, an idea for regional development policy. The early perception of OVOP was to inspire communities in Oita to selectively producing high-quality added-value goods. The OVOP movement suggested one village produce one competitive and marketable product with regards to their local resources to achieve sales revenue in the market, thus creating income for the residents in the villages and enhancing the local economy.

The OVOP approach also inspired local leadership and human resource development at the municipal level by founding several schools for specific training goals. Thanks to the OVOP program, the quantity of OVOP goods in Oita enlarged from 143 goods with total values of $\$ 330$ million in 1980 to 336 products with total values of $\$ 1300$ million in 2001. Throughout that time, the Oita incomes per capita doubled, to which the attainment of the OVOP strategy appears to have contributed. OVOP, from the policymakers' point of view, is useful at bridging the gap between urban and rural areas in developing countries through community-based development. As a result, recently, the OVOP approach has been implemented in many Asian countries and further developing nations, including Africa and Latin America as an alternative economic development path. Additionally, the OVOP movement has become one of the most attractive packages of Japanese ODA (Official Development Assistance) that have a great influence on policymakers.

Problem Number 2. What is the level of financial impact of the marketing assistance provided by DTI IV-A in terms of: Revenue, Marketing Cost, and Net Profit?

\section{Table 2.1}

Financial impact of the marketing assistance in terms of revenue

\begin{tabular}{|c|c|c|}
\hline $\begin{array}{c}\text { Indicators } \\
\text { The Marketing Assistance provided by DTI IV-A in terms of Revenue }\end{array}$ & M & VI \\
\hline 1. Increases msmes sales. & 3.60 & VHI \\
\hline 2. Results to additional resellers or distributors. & 3.30 & VHI \\
\hline $\begin{array}{l}\text { 3. Helps msmes to align their campaigns to support their business towards } \\
\text { profitability. }\end{array}$ & 3.58 & VHI \\
\hline 4. Offers a wide customer base. & 3.35 & VHI \\
\hline 5. Assists msmes to identify marketing tactic types for winning deals. & 3.57 & VHI \\
\hline 6. Capacitates msmes to acquire strategies to match the revenue targets. & 3.50 & VHI \\
\hline General Assessment & 3.48 & VHI \\
\hline
\end{tabular}

Table 2.1 shows the financial impact of the marketing assistance provided by DTI IV-A to the micro, small, and medium enterprises in terms of revenues. This generates a general composite mean of $\mathbf{3 . 4 8}$ and is interpreted as Very High. The indicator Increases MSMEs sales has the highest mean which is $\mathbf{3 . 6 0}$ interpreted as Very High. Meanwhile, the indicator Results to additional resellers or distributors has the least mean of $\mathbf{3 . 3 0}$ and interpreted as Very High. The results suggest that various marketing assistance being provided by DTI IV-A to its MSMEs are effectively generating additional sales. And as regards additional resellers and distributors, it is not easy to gain much as just a few are willing to go into business and there are big brands that are also open for resellers.

In support of the above, Lath (2018) mentioned that marketing for small and medium-sized enterprises can generate more profit. A well-defined marketing strategy leads to an increase in business sales and marketing. This directly impacts the revenue generated as the company reaches out to people, the more it reaches out to its business or brand. The marketing of a business is directly related to the sales it generates. While defining the marketing strategy, the business should also estimate how much of an increase in revenue or sales it expects the strategy to bring about.

Furthermore, Terblanche, Gerber, Erasmus \& Schmidt (2015) emphasized the importance of the marketing function by stating that the financial success of companies often depends on marketing ability and that the lack thereof could be the Achilles' heel of formerly prosperous companies. It is also stated in the study that Ambler 
Marketing assistance to micro, small, and medium enterprises and its financial impact: Inputs to marketing plan (2006) describes marketing as a two-stage process: building brand equity, and then using it to drive cash flow. As a result, if performance is to be benchmarked and monitored, both stages have to be measured. The value of a company is dependent largely on the growth prospects and perceived sustainability of profits.

Moreover, Boykin (2019) cited that marketing typically drives revenue rather than the reverse in most successful businesses. Moreover, marketing and advertising spending in most successful businesses is task- or project-oriented. Task-oriented marketing requires a marketing plan, something most marketing experts strongly recommend. The percentage-of-gross-revenue calculation is a useful ballpark gauge of spending parameters. But, the business needs to be flexible depending on the requirements of its marketing plan. It may be able to obtain specific marketing as a percentage of gross revenue figures for your industry trade association.

Table 2.2 shows the financial impact of the marketing assistance provided by DTI IV-A to the micro, small, and medium enterprises in terms of marketing cost.

\section{Table 2.2}

Financial impact of the marketing assistance in terms of marketing cost

\begin{tabular}{|c|c|c|}
\hline $\begin{array}{c}\text { Indicators } \\
\text { The Marketing Assistance provided by DTI IV-A in terms of Marketing Cost }\end{array}$ & M & VI \\
\hline $\begin{array}{l}\text { 1. Results in economies of scale that positively affects the marketing expenditures of } \\
\text { msmes. }\end{array}$ & 3.50 & VHI \\
\hline 2. Provides free online selling platforms to msmes. & 3.52 & VHI \\
\hline 3. Gives low-cost hubs and stores. & 3.57 & VHI \\
\hline $\begin{array}{l}\text { 4. Offers free product photoshoot for msmes' online stores. (e.i. Lazada, Shopee, } \\
\text { PLDT Home kaasenso, etc.) }\end{array}$ & 3.55 & VHI \\
\hline $\begin{array}{l}\text { 5. Encourages msmes to participate in marketing seminars and training without any } \\
\text { cost. }\end{array}$ & 3.69 & VHI \\
\hline 6. Offers free services of professional designers to improve msmes' products. & 3.59 & VHI \\
\hline 7. Helps msmes reach the export market at a minimal expense. & 3.42 & VHI \\
\hline 8. Provides market exposure to msmes for free. & 3.61 & VHI \\
\hline General Assessment & 3.56 & VHI \\
\hline
\end{tabular}

This generates a general composite mean of $\mathbf{3 . 5 6}$ and is interpreted as Very High Impact. The indicator Encourages MSMEs to participate in marketing seminars and training without any cost has the highest mean which is 3.69 interpreted as Very High Impact. Meanwhile, the indicator Helps MSMEs reach the export market at a minimal expense has the least mean of $\mathbf{3 . 4 2}$ and interpreted as Very High Impact. The results imply that DTI IV-A has been providing various capacity-building assistance that aid the CALABARZON MSMEs to have less expenditure on promotional, advertising, and on different activities that are marketing-related such as participation in cost-free marketing seminars and training. Meanwhile, though the agency is also responsible for realizing the country's goal of a globally competitive and innovative industry and services sector that contributes to inclusive growth and employment generation, it can only support the MSMEs which are willing and ready to export and trade abroad or overseas.

Table 2.3

Financial impact of the marketing assistance in terms of net profit

\begin{tabular}{lll}
\hline \multicolumn{1}{c}{ Indicators } & \multirow{2}{*}{ M } & VI \\
The Marketing Assistance provided by DTI IV-A in terms of Net Profit & 3.58 & VHI \\
\hline 1. Maximizes customer satisfaction towards repeat purchase of msmes' products. & 3.58 & VHI \\
2. Drives business growth. & 3.38 & VHI \\
3. Helps msmes to transact with consumers in any part of the globe. & 3.53 & VHI \\
4. Helps msmes to establish a strong market position. & 3.54 & VHI \\
5. Trains msmes on social media applications to increase sales. & 3.35 & VHI \\
6. Assists msmes to build long-term profitability. $\quad$ General Assessment & 3.56 & VHI \\
\end{tabular}


Table 3.3 shows the financial impact of the marketing assistance provided by DTI IV-A to the micro, small, and medium enterprises in terms of net profit. This generates a general composite mean of $\mathbf{3 . 5 6}$ and is interpreted as Very High Impact. The indicators Maximizes customer satisfaction towards repeat purchase of MSMEs' products and Drives business growth have the highest mean which is $\mathbf{3 . 5 8}$ interpreted as Very High Impact. Meanwhile, the indicator Assist MSMEs to build long-term profitability has the least mean of $\mathbf{3 . 3 5}$ and interpreted as Very High Impact.

The results imply that DTI IV-A efforts specifically on the marketing aspect are providing higher sales to business enterprises due to customer retention and business growth. On the other hand, business for long-term profitability requires sustainable resources and a stable economy. And amid the pandemic both are hard to maintain. Similarly, Gotter (2020) said that repeat customer or high customer retention rates increase profitability. A business would want a retention rate to be as high as possible. This not only ensures maximum profitability but lets the business know that its marketing is sound, the quality of the product or service is strong and that the business is targeting the right people or market.

Saif (2015) cited that marketing strategy in promotion, pricing, distribution, and product standardization and adaptation have an impact on sales, customer, and financial performance of firms. His study contributes to the existing learning of marketing strategy by supporting a relationship between marketing strategy factors and overall firm performance. The study suggests that the impact is mediated by marketing strategy implementation success. Furthermore, Terblanche, Gerber, Erasmus \& Schmidt (2015) emphasized the importance of the marketing function by stating that the financial success of companies often depends on marketing ability and that the lack thereof could be the Achilles' heel of formerly prosperous companies. It is also stated in the study that Ambler (2006) describes marketing as a two-stage process: building brand equity, and then using it to drive cash flow. As a result, if performance is to be benchmarked and monitored, both stages have to be measured. The value of a company is dependent largely on the growth prospects and perceived sustainability of profits.

Problem Number 3. Is there a significant relationship between the level of marketing assistance provided by the Department of Trade and Industry and its financial impact on the MSMEs?

Table 4 shows the test of the significant relationship between the level of marketing assistance provided by the Department of Trade and Industry and its financial impact on the MSMEs.

\section{Table 3}

Test of significant relationship between marketing assistance and financial impact on the MSMEs

\begin{tabular}{|c|c|c|c|c|c|}
\hline Marketing assistance & Financial Impact & r value & $p$-value & Remarks & Decision \\
\hline \multirow[t]{3}{*}{ Physical trade fair } & Revenue & $.713^{* *}$ & .000 & Significant & Reject ho \\
\hline & Marketing Cost & $.704^{* *}$ & .000 & Significant & Reject ho \\
\hline & Net Profit & $.713^{* *}$ & .000 & Significant & Reject ho \\
\hline \multirow[t]{3}{*}{ Virtual trade fair } & Revenue & $.765^{* *}$ & .000 & Significant & Reject ho \\
\hline & Marketing Cost & $.778^{* *}$ & .000 & Significant & Reject ho \\
\hline & Net Profit & $.764^{* * *}$ & .000 & Significant & Reject ho \\
\hline \multirow[t]{3}{*}{ Product development } & Revenue & $.754^{* *}$ & .000 & Significant & Reject ho \\
\hline & Marketing Cost & $.774^{* * *}$ & .000 & Significant & Reject ho \\
\hline & Net Profit & $.741^{* *}$ & .000 & Significant & Reject ho \\
\hline \multirow[t]{3}{*}{ Seminars and training } & Revenue & $.720^{* *}$ & .000 & Significant & Reject ho \\
\hline & Marketing Cost & $.784^{* * *}$ & .000 & Significant & Reject ho \\
\hline & Net Profit & $.741^{* * *}$ & .000 & Significant & Reject ho \\
\hline \multirow[t]{3}{*}{ Provision of hubs and stores } & Revenue & $.794^{* *}$ & .000 & Significant & Reject ho \\
\hline & Marketing Cost & $.782^{* *}$ & .000 & Significant & Reject ho \\
\hline & Net Profit & $.797^{* *}$ & .000 & Significant & Reject ho \\
\hline
\end{tabular}

**. Correlation is significant at the 0.01 level $\quad *$. Correlation is significant at the 0.05 level (2-tailed).

The probability values are all less than the level of significance at .05 thus reject the null hypothesis. It can be concluded that there is a significant relationship between the level of marketing assistance provided by the Department of Trade and Industry and its financial impact on the MSMEs. This implies that the higher the 
Marketing assistance to micro, small, and medium enterprises and its financial impact: Inputs to marketing plan marketing assistance, the higher the financial impact. That DTI IV-A marketing assistance has a significant financial impact on the CALABARZON MSMEs. That the higher the marketing assistance being provided to the local enterprises, the higher revenue and profitability for them on lower marketing activities expenditures.

The DTI IV-A marketing assistance includes but is not limited to the conduct of physical trade fairs (national, regional, and provincial levels), virtual trade fairs, product development, seminars and training, and provision of hubs and stores are all free of charge or with a minimal fee. The presence of the minimum charges is in accordance with the proper expenditure based on the General Appropriations Act (GAA) on different funds such as Organizational Outcomes 1 and 3, Maintenance and Other Operating Expenses (MOOE), and Locally Funded Programs and Projects. The result also goes to show that DTI IV-A marketing assistance is being effectively implemented and is making an impact on the CALABARZON MSMEs. This simply means that DTI's efforts reduce the marketing cost that entrepreneurs should have been paying out of their working capital. But because it is provided by DTI IV-A for free, the MSMEs can save or reduce their marketing cost/expenses. The DTI IV-A marketing activities also provide an opportunity to advertise and promote the MSMEs' products and services and cause them to expand their market reach and increase their revenue. Moreover, due to low marketing costs, MSMEs maintain high net profit.

To support the above, the research of Bhawann (2019) of the Development Commissioner Ministry of Micro, Small \& Medium Enterprises from India studied the importance of marketing assistance to MSMEs with the subject, Procurement and Marketing Support a component of scheme Development of MSMEs and the study eventually has been approved by the Government of India dated 20 November 2019.

The study stated that marketing is a strategic tool for business development and is critical for the growth and survival of MSMEs. Keeping in view these facts, the Procurement and Marketing Support Scheme has been introduced to enhance the marketability of products and services in the MSME sector. The scheme aims to promote new market access initiatives like organizing and participation in National/International Trade Fairs, Exhibitions, MSME Expo, etc. It also aims to create awareness and educate the MSMEs about the importance, methods, and process of packaging in marketing, latest packaging technology, import-export policy and procedure, GeM portal, MSME Conclave, latest developments in international/national trade, and other subjects or topics relevant for market access developments.

Furthermore, Shamsuddoha \& Ndubisi (2019) with the study entitled: Impact of Government Export Assistance on Internationalization of SMEs from developing nations, were found to be in support also of the study because the researcher believed that government assistance should provide financial impact to MSMEs.

Problem Number 4. Based on the findings of the study, what enhancement plan may be proposed to improve the current marketing assistance rendered by DTI IV-A?

As an output, an Enhancement Program was formulated for the Marketing Division of the SME Development Division to have a guide that is concise, conversational, and easy to utilize towards the continuous improvement of the marketing assistance provided to MSMEs.

\section{Table 4}

The proposed enhancement plan

\begin{tabular}{|c|c|c|c|c|c|c|}
\hline $\begin{array}{c}\text { KEY RESULT } \\
\text { AREA } \\
\end{array}$ & OBJECTIVES & $\begin{array}{l}\text { STRATEGIES/ } \\
\text { ACTIVITIES }\end{array}$ & $\begin{array}{c}\text { TIME } \\
\text { FRAME }\end{array}$ & $\begin{array}{c}\text { PERSONS } \\
\text { INVOLVED }\end{array}$ & $\begin{array}{c}\text { SOURCE OF } \\
\text { FUND }\end{array}$ & $\begin{array}{c}\text { SUCCESS } \\
\text { INDICATORS }\end{array}$ \\
\hline $\begin{array}{c}\text { Physical Trade } \\
\text { Fair }\end{array}$ & $\begin{array}{l}\text { To enhance the } \\
\text { provision of } \\
\text { promotional activity } \\
\text { such as quad media } \\
\text { advertisement of the } \\
\text { event }\end{array}$ & $\begin{array}{c}\text { Online and newspaper } \\
\text { press releases } \\
\text { Television \& Radio } \\
\text { interviews } \\
\text { Social media } \\
\text { advertisements }\end{array}$ & $\begin{array}{l}\text { August } \\
2022- \\
\text { October } \\
2022\end{array}$ & $\begin{array}{l}\text { Regional and } \\
\text { Provincial } \\
\text { Trade } \\
\text { Promotion } \\
\text { Officers and } \\
\text { Information } \\
\text { Officers }\end{array}$ & $\begin{array}{l}\text { One Town, One } \\
\text { Product - NextGen } \\
\text { (OTOP-NG) } \\
\text { Program Fund and } \\
\text { Allocable Fund- } \\
\text { Organizational } \\
\text { Outcome (OO) } 3\end{array}$ & $\begin{array}{l}95 \% \\
\text { accomplishment of } \\
\text { the target sales } \\
\text { have been obtained }\end{array}$ \\
\hline
\end{tabular}




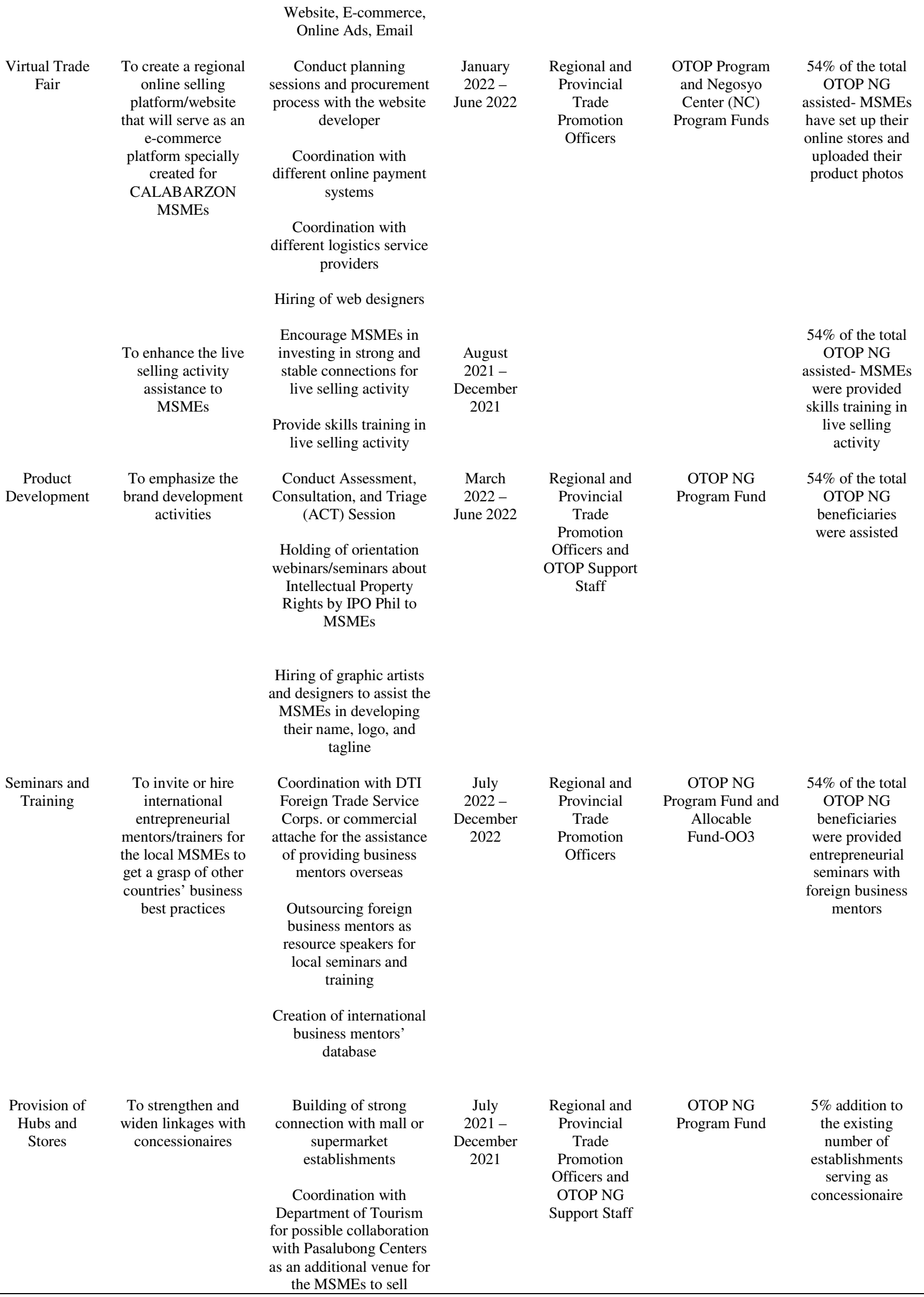


Marketing assistance to micro, small, and medium enterprises and its financial impact: Inputs to marketing plan

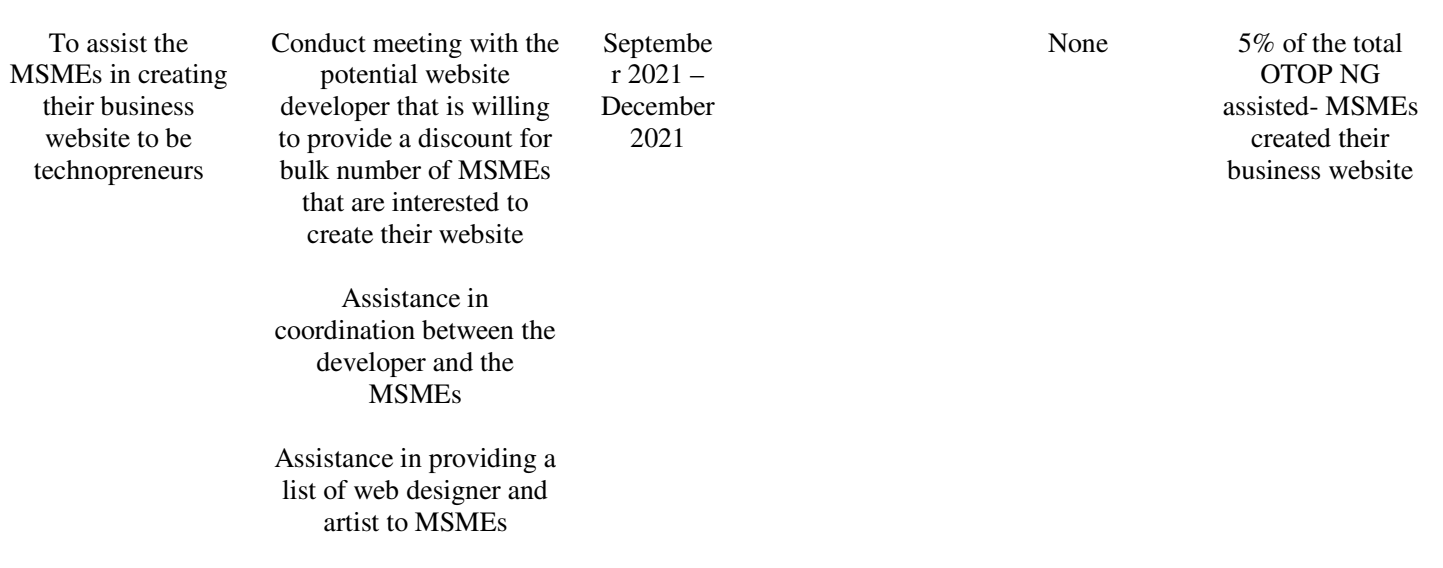

\section{Conclusion}

Based on the aforementioned findings of the study, the following conclusions were derived:

$>\quad$ That MSMEs consider DTI IV-A's provision of an appropriate venue for them to generate higher sales and widen their market reach during the conduct of physical trade fair and that they are enthusiastic to be virtually competitive with other products both locally and globally to serve as their additional support during these digital times and nation's fight against Covid-19 pandemic wherein the full physical operation of the businesses is not possible. In addition, it is also concluded that DTI IV-A is providing the needed assistance of MSMEs in terms of product development and MSMEs are interested to explore more on brand development as this is a tool for them to create their mark in the local and international market and that the agency's Entrepreneurial capacity-building program or the provided seminars and training is the most received assistance of MSMEs among all the provided assistance. This implies that DTI focuses on advancing MSMEs' skills and competencies to succeed locally and internationally. Lastly, it is concluded that DTI IV-A is arranging venues for the MSMEs not only to sell their local products on a minimal concessionaire fee but also to promote and supply their town's local delicacies and handicrafts in different localities.

$>\quad$ That DTI IV-A marketing assistance to MSMEs increases its sales as the company reaches out to different markets and its marketing assistance to MSMEs decreases its marketing cost by providing free or minimal fee through different marketing activities. Furthermore, it is concluded that the agency's marketing assistance to MSMEs ensures maximum profitability by gaining increase sales generation and minimal marketing cost.

$>\quad$ That DTI IV-A marketing assistance has a significant financial impact on the CALABARZON MSMEs. That the higher the marketing assistance being provided to the local enterprises, the higher revenue and profitability for them on lower marketing activities expenditures.

$>\quad$ That based on the quantitative data analysis, there is a need for a proposed enhancement plan focusing on DTI IV-A's marketing assistance on MSMEs. The proposed enhancement program shall be utilized by the DTI regional and provincial offices within CALABARZON which will contribute to the implementation of the program for micro, small, and medium enterprises.

\subsection{Recommendations}

Based on the findings summarized and conclusion drawn, the following recommendations are hereby offered: 
$>$ DTI IV-A is encouraged to sustain its provision of an appropriate venue for its physical trade fair as this kind of marketing activity provides additional profitability for the MSMEs. A sufficient budget for the conduct of such activity is also recommended for enhanced advertisement that will lead the MSMEs to deliver higher sales. The agency is also suggested to continuously communicate to its MSMEs the importance and relevance of participation in e-commerce like virtual trade fairs both locally and globally. The battle is now in the cyber world and the homegrown MSMEs must not be left behind. Especially now that there is a pandemic and various LGUs have quarantine and lockdown guidelines so that businesses can continue to fully operate. In relation to this, DTI IV-A is also recommended to encourage MSMEs in investing to strong and stable internet connections and to assist them in upskilling for live selling in different selling platforms and social media applications. In addition, it is recommended to reinforce its brand development assistance to the MSMEs. This way, MSMEs will continue to create their mark in the local and international market. The executive department is also suggested to maintain its commitment to providing effective and comprehensive entrepreneurial seminars and training to MSMEs. Inviting and adding international business mentors to their pool of mentors database will be a big help as this new class of mentors will provide their country's best practices in different fields of entrepreneurship. Furthermore, it is recommended for the agency to invite different private and government financial institutions to provide financial forums which are relevant these times. Moreover, DTI IV-A is recommended to strengthen its partnership with different commercial establishments such as malls and supermarkets that will serve as an additional breeding ground for the MSMEs and their products to gain further reach. And lastly, it is recommended for the agency to enhance its assistance in creating technopreneurs.

$>\quad$ DTI IV-A is advised to continuously strengthen its campaign in inviting and encouraging the MSMEs to avail of its various marketing activities as this results in high sales generation and wide market reach. The agency is also recommended to unceasingly discover world-class, innovative, and creative marketing assistance to further uplift the standards of the homegrown MSMEs and is suggested to heighten its monitoring and evaluation of the MSMEs' performance specifically in terms of sales generation to assess the key areas that need improvement to ensure that the entrepreneurs are getting the benefits that they are supposed to receive from the marketing activities.

$>$ DTI IV-A is recommended to continue the marketing assistance it is providing to its MSMEs and to further improve and enhance the marketing activities to keep pace with the ever-changing needs of MSMEs.

$>$ DTI IV-A regional and provincial offices are recommended to implement the proposed enhancement plan for them to be guided accordingly with the steps in continuous improvement of the marketing assistance provided to the MSMEs.

$>\quad$ Future researchers may explore the facets of international trade exhibitions and assistance to different legal and mandatory regulatory licenses and certifications.

\section{References}

Bahl, S. (2019). Importance of learning and development in small and medium enterprises. Retrieved December 7, 2020 from: https://www.dqindia.com/importance-learning-development-small-medium-enterprises/

Bhawan, N. (2019). Development Commissioner (MSME), Ministry of Micro, Small \& Medium Enterprises. Retrieved December 9, 2020 from http://www.dcmsme.gov.in/MarketingAssistance.htm

Bindhu, H. (2020). Marketing Assistance Scheme for MSMEs. Retrieved December 7, 2020 from https://www.grainmart.in/news/marketing-assistance-scheme-for-msmes/

Boykin, G. (2019). What Percentage of Gross Revenue Should Be Used for Marketing \& Advertising? Chron. Retrieved May 17, 2021 from 
Marketing assistance to micro, small, and medium enterprises and its financial impact: Inputs to marketing plan https://smallbusiness.chron.com/percentage-gross-revenue-should-used-marketing-advertising-55928.ht $\underline{\mathrm{ml}}$

Bureau of Micro, Small and Medium Enterprise Development (BSMED) (2010). Guide to the Magna Carta for Micro, Small and Medium Enterprises (RA 6977, as amended by RA 8289, and further amended by RA 9501)

Cambridge Dictionary. (2021). Customer Base Meaning. Retrieved May 25, 2021 from https://dictionary.cambridge.org/us/dictionary/english/customer-base

Center for International Trade Expositions and Missions (CITEM). (n.d.). An Attached Agency of the Department of Trade and Industry. Retrieved December 7, 2020 from http://www.citem.gov.ph/

Creswell, J. W. (2014). Research design: Qualitative, quantitative and mixed methods approaches (4th Edition). Thousand Oaks, CA: Sage.

De Martini, C. (2017). Three ways marketing operations impacts revenue. Forrester Research. Retrieved December 07, 2020 from https://go.forrester.com/blogs/marketing-operations-impacts-revenue/

Department of Trade and Industry. (n.d). 2019 MSME Statistics. Retrieved November 18, 2020 from https://www.dti.gov.ph/resources/msme-statistics/

Department of Trade and Industry. (n.d). DTI to utilize digital strategies to help small businesses recover. Retrieved November 18, 2020 from https://www.dti.gov.ph/archives/news-archives/digital-strategies/

Department of Trade and Industry. (n.d). Organization and its Functions. Retrieved November 18, 2020 from https://www.dti.gov.ph/about/the-organization/

Department of Trade and Industry. (n.d.). Foreign Trade Service Corps. Retrieved November 18, 2020 from https://www.dti.gov.ph/overseas/

Domestic Trade Exchange. (n.d.). Bureau of Domestic Trade Promotion. Retrieved November 18, 2020 from https://www.dti.gov.ph/negosyo/dtex/

Drucker, P. F. (1985). Opportunity based theory prolific business management. Retrieved December 07, 2020 from

https://www.coursehero.com/file/p2nbgo1/Opportunity-Based-Theory-Prolific-business-management-a uthor-professor-and/

Gillum, S. (2015). How Marketing Impacts Sales Performance. Forbes. Retrieved December 09, 2020 from https://www.forbes.com/sites/gyro/2013/02/25/how-marketing-impacts-sales-performance/?sh=e8568bb $\underline{14 \mathrm{a} 80}$

Go Lokal Philippines. (n.d.). A market access platform for MSMEs. Retrieved December 07, 2020 from https://www.golokal.dti.gov.ph

Golini, R., \& Gualandris, J. (2018). An empirical examination of the relationship between globalization, integration and sustainable innovation within manufacturing networks. International Journal of Operations \& Production Management, 38(3). https://doi.org/10.1108/IJOPM-12-2016-0725

Hayes, A. (2021). Entrepreneur Meaning. Investopedia. Retrieved May 25, 2021 from https://www.investopedia.com/terms/e/entrepreneur.asp

Hutt, M. D., \& Speh, T. W. (2015). Business Marketing Management. Philippine Edition. 2013-2015 Edition. Cengage Learning. Philippines.

Importance of Learning and Development in Small and Medium Enterprises. (n.d). Data Quest India (2019). Retrieved July 12, 2021 from https://www.dqindia.com/importance-learning-development-small-medium-enterprises/

Johnson, D., \& Shoulders, C. (2019). Beyond magic words and symbols: rethinking common practices in quantitative research. https://doi.org/10.5032/jae.2019.03291

Johnson, M. (2016). Branding: In five and a half steps. Thames and Hudson. London.

Kaleka, A., \& Morgan N. (2019). How marketing capabilities and current performance drive strategic intentional markets. Industrial Marketing Management, 78, 108-121. https://doi.org/10.1016/j.indmarman.2017.02.001

Khaire, M., \& Hall, E. (2016). Medium and message: Globalization and innovation in the production field of Indian Fashion. Organization Studies, 37(6), 845-865. https://doi.org/10.1177/0170840615622061 
Paterno, A.

Knecht, S. (2020). 6 Good Reasons to Exhibit at Virtual Trade Fairs in these times. Retrieved December 7, 2020 from https://www.lumitos.com/en/blog/6-good-reasons-to-exhibit-at-virtual-trade-fairs-in-these-times

Kohli, A. K., \& Jaworski, B. J. (1990). Market orientation: the construct, research propositions, and managerial implications. Journal of Marketing, 54, 1-18. https://doi.org/10.1177/002224299005400201

Lath, A. (2018). The impact of marketing strategy on business performance. BBN Times. Retrieved December 09, 2020 from

https://www.bbntimes.com/companies/the-impact-of-marketing-strategy-on-business-performance

Leaño, R. (2016). Micro, small, and medium enterprise development plan. Retrieved from https://www.yumpu.com/en/document/read/7723439/access-to-markets-a2m-up-institute-for-small-scal e-industries

Maciariello, J. A. (2018). Drucker, Peter: The Drucker strategic management system. The Palgrave Encyclopedia of Strategic Management. Palgrave Macmillan, London. https://doi.org/10.1057/978-1-137-00772-8_629

Markgraf, B. (2018). The profit impact of market strategies. Chron - Small Business. Retrieved December 7, 2020 from https://smallbusiness.chron.com/profit-impact-market-strategies-49771.html

McCombes, S. (2020). Descriptive research meaning. Scribbr. Retrieved May 25, 2021 from https://www.scribbr.com/methodology/descriptive-research/

Mellor, J. (2019). The importance of product development. The Institute for Operations Research and the Management Sciences.

Nijssen, E. J. (2017). Entrepreneurial marketing. An effectual approach. Second Edition. Routledge: Taylor and Francis Group. https://doi.org/10.4324/9781315199863

Osei, A., Shao, Y., Forkuoh, K. S., \& Osei, A .A. (2016). The impact of institutional support in SMEs marketing, and growth. Retrieved December 7, 2020 from https://www.scirp.org/journal/paperinformation.aspx?paperid=67927

Pamaos \& Labao Law Firm. (2020). Micro, small, and medium enterprises: What businesses are considered MSMEs. Retrieved December 7, 2020 from https://pnl-law.com/blog/micro-small-and-medium-enterprises-what-businesses-are-considered-msmes/

Peter, J. P., \& Donnelly, J. H. (2019). A preface to marketing management (15th ed.). McGraw-Hill.

Porral, C. C., \& Stanton, J. L. (2017). Principles of marketing. Esic Editorial.

Porto R., Costa R., \& Watanabe A. (2017). The multilevel effect of marketing activities on sales, revenue, and profitability in a micro-enterprise. University of Basilia. Brazil. https://doi.org/10.7819/rbgn.v19i65.2911

Pramanik, S. A. K. (2015). Opportunity-based entrepreneurship theory. Retrieved May 24, 2021 from https://forum.daffodilvarsity.edu.bd/index.php?topic=32286.0

Pride, W., \& Ferrell, O. (2020). Marketing. RockCity Books.

Pyle, S. O. (2020). How marketing can directly impact revenue with sales enablement. The Business Journals. Retrieved December 7, 2020 from https://www.bizjournals.com/bizjournals/how-to/marketing/2020/02/how-marketing-can-directly-impac t-revenue-with.html

Saif, N. M. A. (2015). How does marketing strategy influence firm performance? Implementation of marketing strategy for firm success. School of Management, Wuhan University of Technology. Wuhan, China.

Salazar, M. S. (2015). Market and market development for small-scale enterprises: the experience of the Philippines. Retrieved December 7, 2020 from http://www.fao.org/3/s8380e08.htm

Shamsuddoha, A. K., Ali, M. Y., \& Ndubisi, N. O. (2019). Impact of Government Export Assistance on Internationalization of SMEs from developing nations. Emerald Group Publishing.

Shouk, M. A., Zoair, N., Farrag, M., \& Hewedi, M. (2018). The roles of international exhibition venues in marketing exhibitor's destinations. Journal of Vacation Marketing, 24(10). https://doi.org/10.1177/1356766717690573

Terblanche, N., Gerber, C., Erasmus, P., \& Schmidt, D. (2015). A marketing perspective on the impact of financial and non-financial measures on shareholder value. Department of Business Management,

58 Consortia Academia Publishing (A Partner of Tourism Educators and Movers of the Philippines) 
Marketing assistance to micro, small, and medium enterprises and its financial impact: Inputs to marketing plan University of Stellenbosch. South Africa.

Thanh, L. H. (2018). One village one product - A rural development strategy and the early adaption in Vietnam. Sustainability. https://doi.org/10.3390/su10124485

Tuovila, A. (2021). Fiscal Year Meaning. Investopedia. Retrieved May 25, 2021 from https://www.investopedia.com/terms//fiscalyear.asp

Venkatesh, J., \& Kumari, R.L. (2015). Role of marketing strategies in the context of MSME Sector. Retrieved December 7, 2020 from http://euroasiapub.org/wp-content/uploads/2016/09/1FMAug-2445-1.pdf

Vokoun, M., \& Pichova, R. (2020). Market orientation and marketing innovation activities in the Czech manufacturing sector. International Journal of Financial Studies. https://doi.org/10.3390/ijfs8010010

Webster, F. E., Jr. (2015). Marketing management “defining the new marketing concept”. McGraw-Hill Companies. 
Paterno, A.

60 Consortia Academia Publishing (A Partner of Tourism Educators and Movers of the Philippines) 